\title{
MicroRNAs-The Heart of Post-Myocardial Infarction Remodeling
}

\author{
Liana Maries ${ }^{1,2}$, Cătălin Marian ${ }^{1,2}$ (D), Raluca Sosdean ${ }^{1,3}$, Flavia Goanta ${ }^{1,3}$, Ioan Ovidiu Sirbu 1,2,*(D) \\ and Andrei Anghel 1,2 \\ 1 Biochemistry Department, "Victor Babes" University of Medicine and Pharmacy Timisoara, \\ 300041 Timisoara, Romania; maries.liana@umft.ro (L.M.); cmarian@umft.ro (C.M.); \\ ralusosdean@yahoo.com (R.S.); flavia2112@yahoo.com (F.G.); biochim@umft.ro (A.A.) \\ 2 Center for Complex Networks Science, "Victor Babes" University of Medicine and Pharmacy Timisoara, \\ 300041 Timisoara, Romania \\ 3 Institute of Cardiovascular and Heart Disease of Timisoara, 300310 Timisoara, Romania \\ * Correspondence: ovidiu.sirbu@umft.ro; Tel.: +40-756-136-272
}

Citation: Maries, L.; Marian, C.;

Sosdean, R.; Goanta, F.; Sirbu, I.O.;

Anghel, A. MicroRNAs-The Heart of Post-Myocardial Infarction Remodeling. Diagnostics 2021, 11, 1675. https://doi.org/10.3390/ diagnostics11091675

Academic Editor: Marcello Ciaccio

Received: 26 June 2021

Accepted: 9 September 2021

Published: 13 September 2021

Publisher's Note: MDPI stays neutral with regard to jurisdictional claims in published maps and institutional affiliations.

\begin{abstract}
Myocardial infarction (MI) is one of the most frequent cardiac emergencies, with significant potential for mortality. One of the major challenges of the post-MI healing response is that replacement fibrosis could lead to left ventricular remodeling (LVR) and heart failure (HF). This process involves canonical and non-canonical transforming growth factor-beta (TGF- $\beta$ ) signaling pathways translating into an intricate activation of cardiac fibroblasts and disproportionate collagen synthesis. Accumulating evidence has indicated that microRNAs (miRNAs) significantly contribute to the modulation of these signaling pathways. This review summarizes the recent updates regarding the molecular mechanisms underlying the role of the over 30 miRNAs involved in post-MI LVR. In addition, we compare the contradictory roles of several multifunctional miRNAs and highlight their potential use in pressure overload and ischemia-induced fibrosis. Finally, we discuss their attractive role as prognostic biomarkers for $\mathrm{HF}$, highlighting the most relevant human trials involving these miRNAs.
\end{abstract}

Keywords: miRNA; myocardial infarction; heart failure; left ventricular remodeling; biomarker; prognostic

\section{Introduction}

Coronary artery disease (CAD) is the leading cause of death for both women and men in developed as well as in developing countries, acute myocardial infarction (MI) being responsible for most of the CAD mortality [1]. Over the past two decades, MI mortality and morbidity have significantly decreased due to extensive prevention programs and effective revascularization procedures. Furthermore, novel drug therapies and standard of care protocols have been implemented to avoid further complications such as life-threatening arrhythmias and heart failure [2].

Post-MI heart failure is the result of left ventricular remodeling (LVR). LVR refers to the ventricular shape, size, and function changes consequent to cardiomyocyte apoptosis and hypertrophy [3]. Ultimately, fibrosis leads to impairment of the left ventricle's systolic and diastolic functions [4], underlining the need for LVR early predictive biomarkers and preventive therapies.

Currently, several circulating biomarkers could predict with decent accuracy post-MI cardiovascular events, of which, N-terminal pro-brain natriuretic peptide (NT-pro-BNP) and cardiac troponin (cTn) are the most promising [5]. However, their use is limited, primarily due to their fluctuating levels in the blood and the influence of other comorbidities, such as renal or hepatic failure [6]. 
MicroRNAs (miRNAs) are a class of small non-coding RNAs that post-transcriptionally regulate gene expression by translational repression or messenger RNA (mRNA) degradation [7]. MiRNAs can, either directly or via other effectors, modulate the remodeling process after MI. The balance between pro-fibrotic miRNAs and anti-fibrotic miRNAs seems to be the key to repairing the injured myocardium. In this review, we highlight the most relevant miRNAs involved in post-MI LVR.

\section{2. miRNAs and Post-MI Remodeling}

\subsection{LVR Mechanisms}

Cardiac remodeling involves three intricate and complex processes (apoptosis, hypertrophy, and fibrosis), of which fibrosis is the main component of post-MI LVR. Cardiac fibrosis evolves as a pathological development of healing if the injury is severe, repeated or the healing response itself becomes dysregulated. Fibrosis represents an uncontrolled accumulation of extracellular matrix (ECM) components (collagen type I and III, elastin, and glycosaminoglycans) produced by fibroblasts and myofibroblasts [8]. In LVR, cardiomyocytes are replaced by connective tissue, leading to the formation of a permanent scar and subsequent loss of function of the affected area.

LVR is initiated in the acute phase of MI when macrophages release factors that stimulate fibroblasts. Most frequently, this factor is transforming growth factor-beta (TGF$\beta$ ), secreted as a latent complex, unable to associate with its receptors. TGF- $\beta$ activation involves cleavage of the $\mathrm{C}$-terminal and $\mathrm{N}$-terminal pro-domains by extracellular proteases, such as furin, plasmin, or Matrix Metalloproteinases (MMP)-2 and MMP-9 [9]. Other cellular pro-fibrotic mediators include connective tissue growth factor (CTGF), plateletderived growth factor (PDGF), tumor necrosis factor alfa (TNF- $\alpha$ ), interleukin 10 (IL-10,) and Angiotensin II (AngII) [10].

TGF- $\beta$ signaling is the fundamental pathway in heart fibrosis. TGF- $\beta$ (as well as CTGF) binds to type I and type II TGF- $\beta$ receptors to form a complex, which initiates a signaling cascade that leads to phosphorylation of Smad (mothers against decapentaplegic homolog) proteins [11]. The activation of TGF- $\beta$ receptor I (TGF $\beta$ RI) phosphorylates Smad 2 and 3 transcription factors in the cytoplasm [11]. The activated Smads form complexes with Smad 4 and translocate to the nucleus, where they induce myofibroblast formation and activate pro-fibrotic genes for collagen (collagen type 1, alpha- 1 gene, collagen type 1 , alpha-2 gene, collagen type 3, alpha-1 gene, etc.), elastin (ELN), fibrillin (FBN), and alfa smooth muscle actin $(\alpha-S M A)$ synthesis [11]. Of note, Smad 7 inhibits TGF- $\beta$ signaling pathway by interfering with the activation of the Smad 2/3 complex [11].

Besides the Smad canonical pathway, TGF- $\beta$ activates many non-canonical signaling pathways, such as ERK (extracellular signal-regulated kinase), MAPK (mitogen-activated protein kinase), AKT (protein kinase B), and NF-KB (nuclear factor kappa-light-chainenhancer of activated B cells) pathways. Ultimately, this leads to proliferation, differentiation, and the activation of fibroblasts, which deposit ECM components in the surrounding tissue $[11,12]$.

\section{2. miRNAs in LVR after MI}

A large number of miRNAs have been associated with the process of fibrosis. In Table 1, we highlight the most significant miRNAs involved in post-MI LVR (Table 1).

MicroRNA modulation of collagen production through canonical/Smad and noncanonical TGF- $\beta$ pathway is instrumental for understanding post-MI fibrosis. Some miRNAs (miR-7, miR-29, miR-34a, miR-92, miR-125b, miR-133a, miR-208, miR-210, miR-370, and miR-1254) target only the canonical/Smad pathway, while others (miR-19a/b, miR-150, miR-199b, miR-223, let-7) target non-Smad pathways at multiple levels (Figures 1 and 2).

MiRNAs colored in green have an anti-fibrotic function; miRNAs colored in red have a pro-fibrotic role. Dash-line arrows indicate the translocation of proteins from the cytoplasm to the nucleus or vice versa; solid line arrows indicate signaling cascades; yellow stars indicate transcription factors. $\alpha$-SMA, alfa smooth muscle actin, AZIN1, antizyme 
inhibitor 1; c-Myb, member of proto-oncogene family Myb; COL1A1, collagen type 1, alpha 1 gene; COL1A2, collagen type 1, alpha 2 gene; CTGF, connective tissue growth factor; $E L N$, elastin gene; ENG, endoglin; $F B N$, fibrillin gene; RI, transforming growth factor-beta receptor I; RII, transforming growth factor-beta receptor II; Smad 2, 3, 4, 7, 2/3, SMAD family members; Snai1, snail family zinc finger 1 ; Sp 1 , specificity protein 1 ; TGF- $\beta$, transforming growth factor-beta.

Table 1. Summary of miRNAs involved in cardiac fibrosis after MI.

\begin{tabular}{|c|c|c|c|c|c|}
\hline miRNA & Effect on Fibrosis & Target & Effector Cells & Platforms & Reference \\
\hline $\mathrm{miR}-7 \mathrm{a} / \mathrm{b}$ & Anti-fibrotic & $\begin{array}{c}S p 1 \\
P A R P-1 \\
T G F \beta\end{array}$ & $\mathrm{CM}$ & $\begin{array}{c}\text { MI mouse } \\
\text { H9C2 cell line } \\
\text { cardiomyoblast }\end{array}$ & [13] \\
\hline miR-9 & Pro-fibrotic & Follistatin-like 1 & $\mathrm{CM}$ & MI mouse & [14] \\
\hline miR-15 family & Pro-fibrotic & $\begin{array}{l}A R L 2 \\
B C L 2\end{array}$ & $\mathrm{CM}$ & $\begin{array}{l}\text { MI pig } \\
\text { MI mouse }\end{array}$ & [15] \\
\hline $\operatorname{miR}-19 a / 19 b$ & Anti-fibrotic & $\begin{array}{c}\text { COL1A1, COL3A1, } \\
\text { ELN, FBN1, } \\
\text { TGF } B \text { RI, PTEN }\end{array}$ & $\begin{array}{c}\mathrm{CM} \\
\mathrm{F} \\
\mathrm{M}\end{array}$ & $\begin{array}{c}\text { MI mouse } \\
\text { Human heart } \\
\text { tissue }\end{array}$ & [16] \\
\hline miR-21 & Pro-fibrotic & $\begin{array}{l}\text { Smad7 } \\
\text { Spry1 } \\
\text { ERK }\end{array}$ & $\begin{array}{c}\mathrm{F} \\
\mathrm{CM} \\
\mathrm{M}\end{array}$ & $\begin{array}{l}\text { MI mouse and pig } \\
\text { NRCFs }\end{array}$ & [17-27] \\
\hline $\operatorname{miR}-22$ & Anti-fibrotic & TGF $\beta R I$ & $\mathrm{~F}$ & $\begin{array}{l}\text { MI mouse } \\
\text { NRCFs }\end{array}$ & [28] \\
\hline $\operatorname{miR}-24$ & Anti-fibrotic & Furin & $\mathrm{F}$ & $\begin{array}{l}\text { MI mouse } \\
\text { NRCFs }\end{array}$ & [29] \\
\hline miR-26a & Pro-fibrotic & $\begin{array}{c}\text { Smad1, BMP } \\
\text { NF- } \kappa B \\
\text { COL1A1 } \\
\text { COL1A2 }\end{array}$ & $\mathrm{EC}$ & $\begin{array}{l}\text { MI mouse } \\
\text { HUVECs } \\
\text { Human trials }\end{array}$ & [30] \\
\hline $\operatorname{miR}-29$ & Anti-fibrotic & $\begin{array}{c}\text { FBN1, COL1A1 } \\
\text { COL1A2, COL3A1 }\end{array}$ & $\mathrm{F}$ & $\begin{array}{l}\text { MI mouse } \\
\text { RCFs }\end{array}$ & [31-33] \\
\hline miR-30a-5p & Anti-fibrotic & $\begin{array}{l}\text { CTGF } \\
\text { TGF } \beta\end{array}$ & $\begin{array}{c}\mathrm{F} \\
\mathrm{CM} \\
\mathrm{EC}\end{array}$ & $\begin{array}{l}\text { MI Rat } \\
\text { NRVMs } \\
\text { NRCFs }\end{array}$ & [34-39] \\
\hline miR-34a & Pro-fibrotic & Smad4 & $\mathrm{F}$ & MI mouse & [40] \\
\hline miR-92 & Pro-fibrotic & $\begin{array}{c}\text { Collagen } 1 \\
\text { IL-6, TNF- } \alpha \\
\text { BCL-2 }\end{array}$ & $\begin{array}{c}\mathrm{F} \\
\mathrm{CM} \\
\mathrm{M}\end{array}$ & $\begin{array}{c}\text { MI rat } \\
\text { Human trials }\end{array}$ & {$[41,42]$} \\
\hline miR-99 & Anti-fibrotic & $m T O R / S 6 K$ & $\mathrm{CM}$ & $\begin{array}{l}\text { MI mouse } \\
\text { NMVMs }\end{array}$ & [43] \\
\hline miR-101 & Anti-fibrotic & $\begin{array}{c}\text { TGF } \beta R 1 \\
c-F o s\end{array}$ & $\mathrm{~F}$ & $\begin{array}{l}\text { MI rat } \\
\text { NRCFs }\end{array}$ & {$[31,44,45]$} \\
\hline $\mathrm{miR}-125 \mathrm{~b}$ & Pro-fibrotic & $\begin{array}{l}\text { TGF } \beta \\
\text { Apelin } \\
\text { p53 } \\
\text { SFRP5 }\end{array}$ & $\mathrm{F}$ & $\begin{array}{c}\text { MI mouse } \\
\text { HCFs } \\
\text { Human heart } \\
\text { tissue }\end{array}$ & {$[46,47]$} \\
\hline miR-133a & Anti-fibrotic & $\begin{array}{l}\text { CTGF } \\
\text { Snai1 } \\
\text { SRF }\end{array}$ & $\begin{array}{c}\mathrm{CM} \\
\mathrm{F}\end{array}$ & $\begin{array}{l}\text { MI mouse } \\
\text { NRCFs }\end{array}$ & {$[48,49]$} \\
\hline miR-144 & Anti-fibrotic & ZEB1/LOX axis & $\mathrm{F}$ & $\begin{array}{l}\text { MI mouse } \\
\text { NRCFs }\end{array}$ & {$[50,51]$} \\
\hline
\end{tabular}


Table 1. Cont.

\begin{tabular}{|c|c|c|c|c|c|}
\hline miRNA & Effect on Fibrosis & Target & Effector Cells & Platforms & Reference \\
\hline miR-146 & Anti-fibrotic & $\begin{array}{l}\text { Smad4 } \\
\text { IRAK1 } \\
\text { TRAF6 }\end{array}$ & $\begin{array}{c}\mathrm{F} \\
\mathrm{CM}\end{array}$ & $\begin{array}{l}\text { MI mouse } \\
\text { NRCMs } \\
\text { CDC }\end{array}$ & [52] \\
\hline miR-150 & Anti-fibrotic & $\begin{array}{c}E G R 2 \\
P 2 \times 7 R \\
C X C R 4\end{array}$ & $\begin{array}{c}\mathrm{F} \\
\mathrm{CM} \\
\mathrm{M}\end{array}$ & $\begin{array}{l}\text { MI mouse } \\
\text { Human trials }\end{array}$ & {$[53,54]$} \\
\hline $\operatorname{miR}-155$ & Pro-fibrotic & SOCS1 & M & $\begin{array}{l}\text { MI mouse } \\
\text { PCMs }\end{array}$ & [55] \\
\hline miR-199b & Pro-fibrotic & $\begin{array}{l}\text { NOTCH1 } \\
\text { JAG1 } \\
\text { DYRK1A }\end{array}$ & $\mathrm{CM}$ & MI mouse & [56] \\
\hline miR-208a & Pro-fibrotic & Endoglin & $\mathrm{F}$ & $\begin{array}{l}\text { MI rat } \\
\text { RCFs }\end{array}$ & [57] \\
\hline $\operatorname{miR}-210$ & Anti-fibrotic & $\begin{array}{l}\text { EFNA3 } \\
\text { PTP1 } \\
\text { DAPK1 } \\
\text { CTGF }\end{array}$ & $\begin{array}{c}\mathrm{CM} \\
\mathrm{F}\end{array}$ & $\begin{array}{c}\text { MI mouse } \\
\text { Mouse HL-1 CMs }\end{array}$ & [58] \\
\hline $\mathrm{miR}-214$ & Anti-fibrotic & PTEN & $\mathrm{CM}$ & MI rat & [59] \\
\hline $\operatorname{miR}-223$ & Pro-fibrotic & RASA1 & $\mathrm{F}$ & $\begin{array}{c}\text { MI mouse } \\
\text { Cultured cardiac } \\
\text { fibroblasts }\end{array}$ & [60] \\
\hline $\operatorname{miR}-370$ & Anti-fibrotic & TGF $\beta R I I$ & $\begin{array}{c}\mathrm{F} \\
\mathrm{CM}\end{array}$ & $\begin{array}{c}\text { MI rat } \\
\text { RCFs }\end{array}$ & [61] \\
\hline $\operatorname{miR}-384$ & Anti-fibrotic & $\begin{array}{l}\text { TGF } \beta R I / W n t(3 a) / N F- \\
k b\end{array}$ & $\mathrm{~F}$ & $\begin{array}{l}\text { I/R rats } \\
\text { NRCFs }\end{array}$ & {$[62]$} \\
\hline $\operatorname{miR}-433$ & Pro-fibrotic & $\begin{array}{l}\text { AZIN1 } \\
\text { JNK1 }\end{array}$ & $\mathrm{F}$ & $\begin{array}{l}\text { MI mouse } \\
\text { NRCFs }\end{array}$ & [63] \\
\hline Let-7c & Pro-fibrotic & $\begin{array}{c}\text { OCT4 } \\
\text { SOX2 } \\
\text { TGF } \beta R I I I / p 38\end{array}$ & $\begin{array}{c}\mathrm{F} \\
\mathrm{CM}\end{array}$ & $\begin{array}{l}\text { MI mouse } \\
\text { AMCFs } \\
\text { MI pig }\end{array}$ & {$[64,65]$} \\
\hline
\end{tabular}

AMCFs, adult mouse cardiac fibroblasts; ARL2, ADP-Ribosylation Factor-Like Protein 2; BCL2, Apoptosis Regulator BCL2; BMP, bone morphogenetic protein; $c$-fos, Fos Proto-Oncogene; CDC, cardiosphere-derived cells; CM, cardiomyocyte; COL1A1, collagen type 1, alpha 1 gene; COL3A1, collagen type 3, alpha 1 gene; CTGF, connective tissue growth factor; DAPK1, Death-associated protein kinase 1; DYRK1A, dual specificity tyrosine-phosphorylation-regulated kinase 1A; EC, endothelial cell; EFNA3, Ephrin A3; EGR-2, early growth response protein 2; ELN, elastin gene; $E R K$, extracellular signal-regulated kinase; F, fibroblast; $F B N$, fibrillin gene; HCFs, human cardiac fibroblasts; HUVECs, Human Umbilical Vein Endothelial Cells; I/R, ischemia/reperfusion; IL-6, Interleukin 6; IRAK1, interleukin-1 receptor-associated kinase 1; JAG1, jagged 1 protein; PARP1, Poly [ADP-ribose] polymerase 1; M, macrophage; MI, myocardial infarction; $m T O R$, mammalian target of rapamycin protein; NMVMs, neonatal mice ventricular myocytes; NOTCH1, Notch receptor 1; NRCFs, Neonatal rat cardiac fibroblasts; NRCMs, neonatal rat cardiac myocytes; OCT4, octamer-binding transcription factor 4; P2RX7, P2X purinoceptor 7; PCMs, primary cultured macrophages; PTEN, phosphatase and tensin homolog protein; PTP1, Protein-tyrosine phosphatase 1; RASA1, Ras GTPase activating protein 1; RCFs, rat cardiac fibroblasts; S6K, ribosomal protein S6 kinase beta-1; SFRP5, secreted frizzled-related protein 5; Smad 1, 4, 7, SMAD family members; Snai1, snail family zinc finger 1; SOCS1, Suppressor of cytokine signaling 1; Sp1, specificity protein 1; Spry1, sprouty homologue 1; SRF, Serum Response Factor; TGF $\beta$, transforming growth factor beta; TGF $\beta R I$, transforming growth factor beta receptor I; TGF $\beta R I I$, transforming growth factor beta receptor II; TNF- $\alpha$, tumor necrosis factor alfa; TRAF6, tumor necrosis factor receptor associated factor 6 .

MiRNAs can either directly or indirectly modulate collagen synthesis and other molecules involved in the progression of cardiac fibrosis. Most of the miRNAs involved in post-MI LVR modulate the TGF $\beta$ signaling pathway through fibroblast activation, while others (e.g., miR-7, miR-146, miR-199, miR-214) are linked to fibrosis through cardiomyocytes' apoptosis. Interestingly, the activity of these miRNAs is cell-specific: miR-15, miR-133a, miR-146, miR-210, miR-370 in cardiomyocytes and fibroblasts; miR-21, miR26a in endothelial cells, miR-155 in macrophages; and, exceptionally, miR-19a/19b in cardiomyocytes, fibroblasts, and macrophages. 


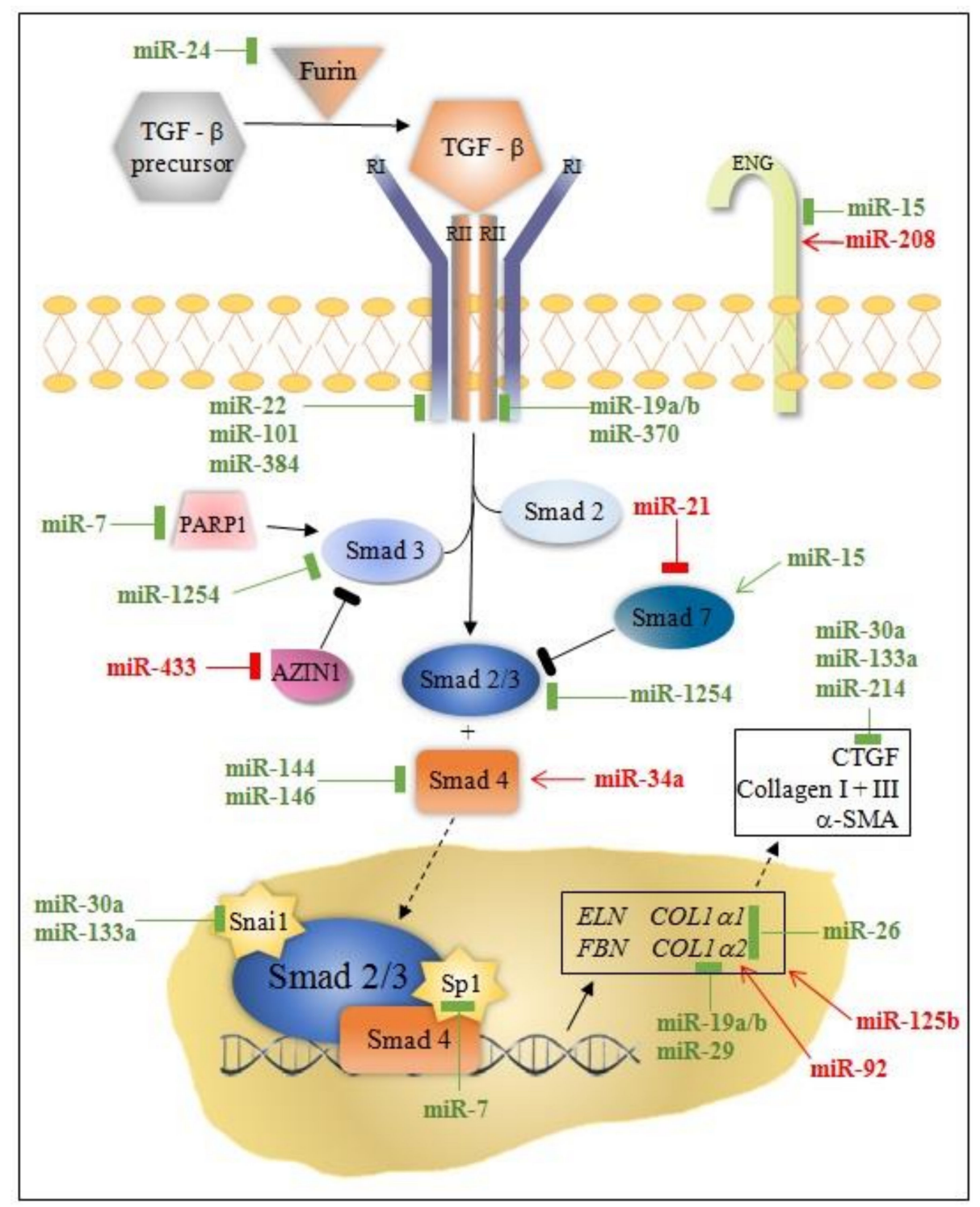

Figure 1. Schematic representation of the canonical TGF- $\beta$ signaling pathway and related miRNAs.

However, although TGF $\beta$ is the central signaling in post-MI LVR fibrosis, it appears that only modulating the expression of miRNAs associated with this pathway is not enough to achieve a proper healing response. Furthermore, none of these miRNAs can be considered by itself a bona fide prognostic biomarker or a therapeutic target.

\subsection{Multifunctional miRNAs}

Individual miRNAs can modulate signaling pathways in more than one cell type, suggesting they regulate multiple target genes and have various functions in post-MI LVR [66]. Most of these miRNAs have a role in cardiomyocyte death or hypertrophy, while some control the angiogenesis process and/or the inflammatory response (Table 2).

The advent of microRNA research in MI prompted novel therapeutic approaches aiming to modulate cardiac remodeling through in vivo manipulation of miRNAs levels microRNA-mimics and antagomirs. miRNA-based therapeutics have the potential of becoming a whole new class of drugs in the treatment of MI. The ideal cocktail of miRNAs to prevent post-MI LVR would consist of specific multifunctional miRNAs targeting multiple pathways of this process. For example, combining miR-mimics for miR-19a/19b, miR-26, miR-133a, and miR-210 with antagomirs for miR-21, miR-92, and miR-155 might lead to a better outcome of MI events, with less scarring tissue, less inflammation, and increased cardiomyocyte regeneration leading to improved cardiac function. 


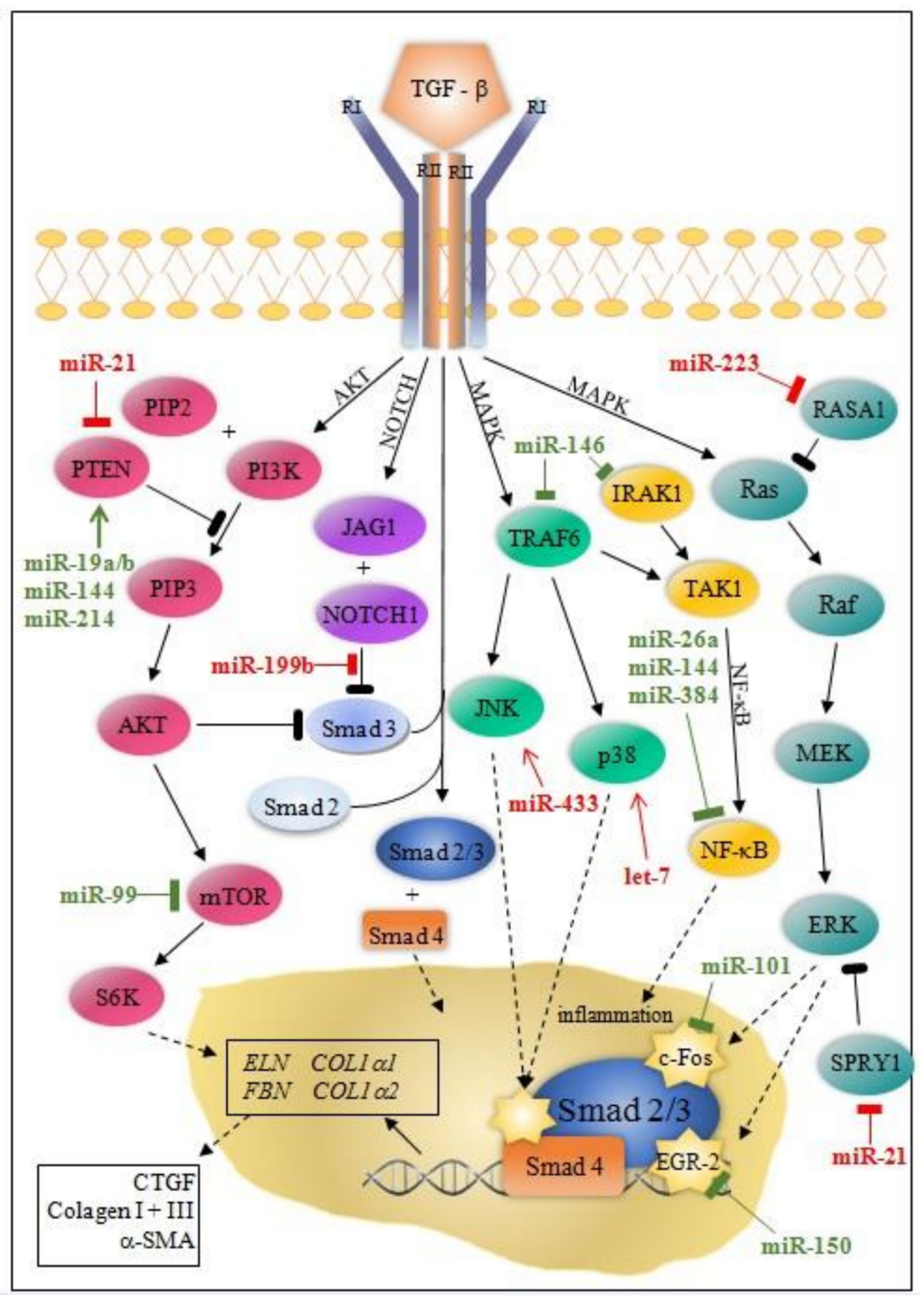

Figure 2. Schematic representation of the non-canonical TGF- $\beta$ signaling pathway and related miRNAs. MiRNAs colored in green have an anti-fibrotic function; miRNAs colored in red have a pro-fibrotic role. Dash-line arrows indicate the translocation of proteins from the cytoplasm to the nucleus or vice versa; solid line arrows indicate signaling cascades; yellow stars indicate transcription factors. $\alpha$-SMA, alfa smooth muscle actin, AKT, protein kinase B; c-fos, Fos Proto-Oncogene, AP-1 transcription factor subunit, COL1A1, collagen type 1, alpha 1 gene; COL1A2, collagen type 1, alpha 2 gene; CTGF, connective tissue growth factor; EGR-1, early growth response protein 1; ELN, elastin gene; ERK, extracellular signal-regulated kinase, $F B N$, fibrillin gene; IRAK1, interleukin-1 receptor-associated kinase 1; JAG1, jagged 1 protein; JNK, c-Jun N-terminal kinases; MAPK, mitogenactivated protein kinase; MEK, mitogen-activated protein kinase kinase; mTOR, mammalian target of rapamycin protein; NF- $\mathrm{B}$, nuclear factor kappa-light-chain-enhancer of activated B cells; NOTCH1, Notch receptor 1; P38, p38 mitogen-activated protein kinases; PI3K, phosphoinositide 3-kinases; PIP2, phosphatidylinositol 4,5-bisphosphate; PIP3, phosphatidylinositol (3,4,5)-trisphosphate; PTEN, phosphatase and tensin homolog protein; Raf, Proto-Oncogene, Serine/Threonine Kinase; Ras, Ras Proto-Oncogene, GTPase family; RI, transforming growth factor beta receptor I; RII, transforming growth factor beta receptor II; S6K, ribosomal protein S6 kinase beta-1; Smad 2, 3, 4, 2/3, SMAD family members; TAK1, mitogen-activated protein kinase kinase kinase 7 or transforming growth factor-beta-activated kinase 1 ; TGF- $\beta$, transforming growth factor beta, TRAF6, tumor necrosis factor receptor associated factor 6 . 
Table 2. Summary of multifunctional miRNAs in myocardial infarction.

\begin{tabular}{|c|c|c|c|c|c|c|}
\hline miRNA & Fibrosis & Hypertrophy & Apoptosis & Angiogenesis & Inflammation & Reference \\
\hline $\operatorname{miR}-19 a / 19 b$ & - & - (Ang II model) & - & - & - & {$[16,67,68]$} \\
\hline miR-21 & + & + & - & + & - & {$[19-27,69]$} \\
\hline miR-26 & - & $\begin{array}{c}-(\mathrm{TAC}, \text { AngII model, } \\
\text { exercise-induced) }\end{array}$ & - & - & - & {$[30,70-73]$} \\
\hline miR-92 & + & + (exercise-induced) & + & + & + & {$[41,42,74,75]$} \\
\hline miR-133a & - & - & - & - & - & {$[48,49,76,77]$} \\
\hline miR-155 & + & + & + & + arteriogenic & + & {$[55,78,79]$} \\
\hline miR-210 & - & - & - & + & - & {$[58,80,81]$} \\
\hline
\end{tabular}

AngII, angiotensin II; TAC, transverse aortic constriction. + indicates that the miRNA promotes the function, - indicates that the miRNA inhibits the function.

\section{4. miRNAs and Remodeling Induced by Pressure Overload}

Cardiac remodeling is mediated by miRNAs that exert different functions by regulating various downstream pathways, depending on whether the trigger is MI or pressure overload (Table 3).

Table 3. Comparison between miRNAs involved in fibrosis induced by MI vs. pressure overload.

\begin{tabular}{|c|c|c|c|c|c|c|}
\hline Ref. & $\begin{array}{l}\text { Signaling } \\
\text { Pathway }\end{array}$ & $\begin{array}{c}\text { Fibrosis } \\
\text { Induced by MI }\end{array}$ & $\operatorname{miRNA}$ & $\begin{array}{l}\text { Fibrosis Induced by } \\
\text { Pressure Overload }\end{array}$ & $\begin{array}{l}\text { Signaling } \\
\text { Pathway }\end{array}$ & Ref. \\
\hline$[15]$ & $\begin{array}{l}A R L 2 \\
B C L 2\end{array}$ & Pro-fibrosis & miR-15b & Anti-fibrosis (TAC) & Smad3 TGF $\beta R I$ & {$[82]$} \\
\hline$[16]$ & $\begin{array}{c}\text { COL1 } 1 \alpha 1 \\
\text { COL } 3 \alpha 1, E L N, \\
\text { FBN, TGF } \beta R I I, \\
\text { PTEN }\end{array}$ & Anti-fibrosis & $\operatorname{miR}-19 a / b$ & \multicolumn{2}{|c|}{ No modification (TAC) } & [16] \\
\hline$[16,18-26]$ & $\begin{array}{c}\text { Smad7 } \\
\text { Spry1 } \\
\text { ERK }\end{array}$ & Pro-fibrosis & miR-21 & Pro-fibrosis (TAC) & Spry1 ERK & {$[27]$} \\
\hline$[30]$ & $\begin{array}{c}\text { Smad1, BMP } \\
\text { NF- } \kappa B \\
C O L 1 \alpha 1 \\
C O L 1 \alpha 2\end{array}$ & Pro-fibrosis & miR-26a & $\begin{array}{l}\text { Anti-fibrosis } \\
(\mathrm{TAC}+A n g I I)\end{array}$ & $\begin{array}{c}C T G F \\
N F-\kappa B \\
C O L 1 \alpha 1\end{array}$ & [83] \\
\hline$[40]$ & Smad4 & Pro-fibrosis & $\operatorname{miR}-34$ & Pro-fibrosis (TAC) & $\begin{array}{c}\text { VEGF } \\
\text { POFUT1 } \\
\text { NOTCH1 } \\
\text { Vinculin } \\
\text { Semaphorin } 4 B\end{array}$ & {$[84]$} \\
\hline [56] & $\begin{array}{c}\text { NOTCH1 } \\
\text { JAG1 } \\
\text { DYRK1A }\end{array}$ & Pro-fibrosis & miR-199b & Pro-fibrosis (TAC) & $D Y R K 1 A$ & [85] \\
\hline$[64,65]$ & $\begin{array}{c}\text { OCT4 } \\
\text { SOX2 } \\
\text { TGF } \beta \text { RIII/p38 }\end{array}$ & Pro-fibrosis & $\begin{array}{l}\text { Let-7c } \\
\text { Let-7i }\end{array}$ & Anti-fibrosis $(A n g I I)$ & $\begin{array}{c}I L-6 \\
C O L 1 \alpha 2 \\
C O L 3 \alpha 1 \\
C O L 4 \alpha 1 \\
C O L 5 \alpha 2\end{array}$ & {$[86]$} \\
\hline
\end{tabular}

AngII, angiotensin II; ARL2, ADP-Ribosylation Factor-Like Protein 2; BCL2, Apoptosis Regulator BCL2; COL1 $\alpha 1$, collagen type 1, alpha 1 gene; COL1 $\alpha 2$, collagen type 1, alpha 2 gene; COL3 $\alpha 1$, collagen type 3, alpha 1 gene; COL4 $\alpha 1$, collagen type 4 , alpha 1 gene; COL5 2 , collagen type 5, alpha 2 gene; $C T G F$, connective tissue growth factor; $D Y R K 1 A$, dual specificity tyrosine-phosphorylation-regulated kinase 1A; ELN, elastin gene; ERK, extracellular signal-regulated kinase; $F B N$, fibrillin gene; IL-6, interleukin 6; JAG1, jagged 1 protein; NOTCH1, Notch receptor 1; OCT4, octamer-binding transcription factor 4; POFUT1, GDP-fucose protein O-fucosyltransferase 1; PTEN, phosphatase and tensin homolog protein; Smad 1, 3, 4, SMAD family members; TAC, transverse aortic constriction; TGF $\beta R I$, transforming growth factor-beta receptor I; TGF $\beta R I I$, transforming growth factor-beta receptor II; TGF $\beta R I I I$, transforming growth factor-beta receptor III; VEGF, Vascular endothelial growth factor. 
Several miRNAs (miR-21, miR-34, miR-199b) have similar roles in cardiac fibrosis post-MI or induced by TAC/AngII and even share some of the downstream targets: (miR-34 and miR-21) in the two fibrosis settings. At the same time, miR-15b and miR-26a have opposing roles in the two LVR settings. Post-MI, miR-15b induced involves modulation of apoptosis and hypertrophy, while post-fibrotic overload fibrosis utilizes the TGF $\beta$ pathway. MiR-26a exploits TGF $\beta$ canonical and non-canonical (through NF- $\mathrm{kB}$ ) pathways to reach divergent effects on fibrosis in the two scenarios. Interestingly, while miR-19a/b has a pronounced anti-fibrotic effect post-MI, no changes in its plasma levels were detected in a TAC mouse model. The two members of the Let-7 family also have opposing effects on cardiac remodeling and target different genes. Let-7c has a pro-fibrotic effect by stimulating proliferation and differentiation in fibroblasts and apoptosis in cardiomyocytes, while let-7i has an anti-fibrotic effect modulation of inflammation and collagen genes' expression.

Multiple questions arise related to these paradoxical findings. Could they be justified solely by the mechanism which initiated the remodeling? Are these miRNAs secreted in antagonistic pairs through common regulatory mechanisms? Do miRNA targeting specificity changes in the different cellular contexts and triggering pathophysiological MI mechanisms? Although the molecular and cellular processes underlying miRNA-related cardiac fibrosis in both situations are rapidly disentangled, much remains to be learned regarding the role of these molecules.

\section{3. miRNAs as Prognostic Biomarkers of Post-MI LVR}

Besides their diagnostic use, MI-associated miRNAs are also considered as potential prognostic biomarkers. Next, we examine the emerging prognostic role of several circulating miRNAs in post-MI LVR (Table 4).

Table 4. MiRNAs studied as prognostic biomarkers for LVR after MI.

\begin{tabular}{|c|c|c|c|c|c|c|}
\hline miRNA & Effect on LVR & Study Population & $\begin{array}{l}\text { Blood Sample } \\
\text { Collection }\end{array}$ & $\begin{array}{c}\text { Method for } \\
\text { Assessing LVR }\end{array}$ & $\begin{array}{l}\text { Definition of } \\
\text { LVR }\end{array}$ & Reference \\
\hline \multirow{3}{*}{ miR-1 } & + & $\begin{array}{c}80 \text { patients } \\
\text { with STEMI }\end{array}$ & On admission & $\begin{array}{l}\text { CMR at } 1 \text { and } \\
6 \text { months }\end{array}$ & $\begin{array}{l}\uparrow>10 \% \text { of } \\
\Delta \mathrm{LVEDV}\end{array}$ & [87] \\
\hline & - & $\begin{array}{l}44 \text { patients with MI } \\
\text { (SITAGRAMI trial) }\end{array}$ & $\mathrm{d} 4, \mathrm{~d} 9,6 \mathrm{~m}$ & CMR at $4 \mathrm{~d}, 6 \mathrm{~m}$ & $\begin{array}{l}\text { Absolute change } \\
\text { for LVEDV }\end{array}$ & [88] \\
\hline & No effect & 12 patients with MI & $\mathrm{d} 2,5,28,90$ & $\begin{array}{l}\text { Echo on } \mathrm{d} 1,5, \\
28,90\end{array}$ & $\begin{array}{l}\text { Absolute change } \\
\text { for LVEDV }\end{array}$ & [89] \\
\hline $\begin{array}{c}\mathrm{miR}-16 / \\
\text { 27a/101/150 }\end{array}$ & $\begin{array}{c}+ \text { for } \\
\text { miR-16/27a } \\
- \text { for miR } \\
150 / 101\end{array}$ & 150 patients with MI & At discharge & $\begin{array}{c}\text { Echo at } \\
\text { discharge and } \\
\text { at a median of } \\
176 \mathrm{~d} \text { (range } \\
128-262 \mathrm{~d}) \\
\text { after MI }\end{array}$ & $\begin{array}{c}\text { Wall Motion } \\
\text { Index Score > } 1.2\end{array}$ & [90] \\
\hline \multirow{5}{*}{ miR-21 } & + & $\begin{array}{c}246 \text { patients with } \\
\text { anterior MI } \\
\text { (REVE trial) }\end{array}$ & $\begin{array}{l}\text { At discharge, } \\
1 \mathrm{~m}, 3 \mathrm{~m}, 1 \mathrm{y}\end{array}$ & $\begin{array}{l}\text { Echo on } \mathrm{d} 3,7 \\
\quad 3 \mathrm{~m}, 1 \mathrm{y}\end{array}$ & $\begin{array}{l}\text { ((EDV1year- } \\
\text { EDVbaseline)/ } \\
\text { EDVbaseline) }\end{array}$ & [91] \\
\hline & + & 184 patients with MI & On admission & - & $\begin{array}{l}\text { Death within } \\
30 \text { days }\end{array}$ & [92] \\
\hline & + & 198 patients with MI & d5 & Echo on d5, 1 y & $\uparrow>20 \%$ of LVEDV & [93] \\
\hline & No effect & $\begin{array}{l}44 \text { patients with MI } \\
\text { (SITAGRAMI trial) }\end{array}$ & $\mathrm{d} 4, \mathrm{~d} 9,6 \mathrm{~m}$ & CMR at $4 \mathrm{~d}, 6 \mathrm{~m}$ & $\begin{array}{l}\text { Absolute change } \\
\text { for LVEDV }\end{array}$ & [88] \\
\hline & No effect & 12 patients with MI & $\mathrm{d} 2,5,28,90$ & $\begin{array}{l}\text { Echo on } \mathrm{d} 1,5, \\
28,90\end{array}$ & $\begin{array}{l}\text { Absolute change } \\
\text { for LVEDV }\end{array}$ & [89] \\
\hline $\operatorname{miR}-29 a$ & + & 12 patients with MI & $\mathrm{d} 2,5,28,90$ & $\begin{array}{c}\text { Echo on } \mathrm{d} 1,5, \\
28,90\end{array}$ & $\begin{array}{l}\text { Absolute change } \\
\text { for LVEDV }\end{array}$ & [89] \\
\hline
\end{tabular}


Table 4. Cont.

\begin{tabular}{|c|c|c|c|c|c|c|}
\hline miRNA & Effect on LVR & Study Population & $\begin{array}{l}\text { Blood Sample } \\
\text { Collection }\end{array}$ & $\begin{array}{c}\text { Method for } \\
\text { Assessing LVR }\end{array}$ & $\begin{array}{l}\text { Definition of } \\
\text { LVR }\end{array}$ & Reference \\
\hline miR-29b & - & $\begin{array}{l}44 \text { patients with MI } \\
\text { (SITAGRAMI trial) }\end{array}$ & $\mathrm{d} 4, \mathrm{~d} 9,6 \mathrm{~m}$ & CMR at $4 \mathrm{~d}, 6 \mathrm{~m}$ & $\begin{array}{l}\text { Absolute change } \\
\text { for LVEDV }\end{array}$ & [88] \\
\hline miR-30a-5p & + & $\begin{array}{l}14 \text { patients with } \\
\text { STEMI }\end{array}$ & $\begin{array}{l}\text { On admission, } \\
6 \mathrm{~m}\end{array}$ & $\begin{array}{c}\text { Echo on } \\
\text { admission, } 6 \mathrm{~m}\end{array}$ & $\begin{array}{c}\text { LVEF } \leq 50 \% \\
\text { NT-proBNP } \geq \\
150 \mathrm{pg} / \mathrm{ml}\end{array}$ & [94] \\
\hline $\mathrm{miR}-34 \mathrm{a}$ & + & 359 patients with MI & On admission & $\begin{array}{c}\text { Echo after } \\
\text { admission, } 6 \mathrm{~m}\end{array}$ & $\uparrow>10 \%$ of LVEDV & [95] \\
\hline $\operatorname{miR}-92 a$ & + & 60 patients with MI & $\begin{array}{l}\text { On admission } \\
\text { and after PCI }\end{array}$ & $\begin{array}{c}\text { Echo on } \\
\text { admission, } 3 \mathrm{~m}\end{array}$ & $\begin{array}{l}\text { Absolute change } \\
\text { for LVEDV, } \\
\text { LVESV, LVEF }\end{array}$ & [41] \\
\hline miR-92 & No effect & $\begin{array}{l}44 \text { patients with MI } \\
\text { (SITAGRAMI trial) }\end{array}$ & $\mathrm{d} 4, \mathrm{~d} 9,6 \mathrm{~m}$ & CMR at $4 \mathrm{~d}, 6 \mathrm{~m}$ & $\begin{array}{l}\text { Absolute change } \\
\text { for LVEDV }\end{array}$ & [88] \\
\hline \multirow[t]{2}{*}{ miR-133a } & No effect & $\begin{array}{l}246 \text { patients with } \\
\text { anterior MI } \\
\text { (REVE trial) }\end{array}$ & $\begin{array}{l}\text { At discharge, } \\
1 \mathrm{~m}, 3 \mathrm{~m}, 1 \mathrm{y}\end{array}$ & $\begin{array}{l}\text { Echo on } \mathrm{d} 3,7 \\
\quad 3 \mathrm{~m}, 1 \mathrm{y}\end{array}$ & $\begin{array}{c}\text { ((EDV1year- } \\
\text { EDVbaseline)/ } \\
\text { EDVbaseline) }\end{array}$ & [96] \\
\hline & No effect & 12 patients with MI & $\mathrm{d} 2,5,28,90$ & $\begin{array}{l}\text { Echo on } \mathrm{d} 1,5, \\
28,90\end{array}$ & $\begin{array}{l}\text { Absolute change } \\
\text { for LVEDV }\end{array}$ & [89] \\
\hline miR-146a & + & 198 patients with MI & d5 & Echo on d5, 1 y & $\uparrow>20 \%$ of LVEDV & [92] \\
\hline $\operatorname{miR}-150$ & - & 60 patients with MI & At discharge & $\begin{array}{c}\text { Echo at } \\
\text { discharge, } 6 \mathrm{~m}\end{array}$ & $\Delta \mathrm{EDV}>0$ & [97] \\
\hline \multirow{3}{*}{ miR-208b } & + & 359 patients with MI & On admission & $\begin{array}{c}\text { Echo after } \\
\text { admission, } 6 \mathrm{~m}\end{array}$ & $\uparrow>10 \%$ of LVEDV & [95] \\
\hline & + & $\begin{array}{l}100 \text { patients with } \mathrm{MI} \text {, } \\
80 \text { patients with UA } \\
80 \text { healthy controls }\end{array}$ & $\begin{array}{l}\text { On admission } \\
\text { and after PCI }\end{array}$ & $\begin{array}{c}\text { Echo on } \\
\text { admission, } 6 \mathrm{~m}\end{array}$ & $\uparrow>10 \%$ of LVEDV & [98] \\
\hline & + & $\begin{array}{l}21 \text { patients with } \\
\text { STEMI }\end{array}$ & On admission & - & Death within 6m & [99] \\
\hline $\operatorname{miR}-208$ & No effect & 12 patients with MI & $\mathrm{d} 2,5,28,90$ & $\begin{array}{l}\text { Echo on } \mathrm{d} 1,5, \\
28,90\end{array}$ & $\begin{array}{l}\text { Absolute change } \\
\text { for LVEDV }\end{array}$ & [89] \\
\hline $\operatorname{miR}-423-5 p$ & No effect & $\begin{array}{c}246 \text { patients with } \\
\text { anterior MI } \\
\text { (REVE trial) }\end{array}$ & $\begin{array}{l}\text { At discharge, } \\
1 \mathrm{~m}, 3 \mathrm{~m}, 1 \mathrm{y}\end{array}$ & $\begin{array}{l}\text { Echo on } \mathrm{d} 3,7 \\
\quad 3 \mathrm{~m}, 1 \mathrm{y}\end{array}$ & $\begin{array}{l}\text { ((EDV1year- } \\
\text { EDVbaseline)/ } \\
\text { EDVbaseline) }\end{array}$ & [96] \\
\hline miR-1254 & - & $\begin{array}{l}70 \text { patients } \\
\text { with STEMI }\end{array}$ & On admission & $\begin{array}{l}\text { CMR at } \\
1 \mathrm{w}, 6 \mathrm{~m}\end{array}$ & $\begin{array}{c}\text { Absolute change } \\
\text { for LVEDV, } \\
\text { LVESV, LVEF }\end{array}$ & [100] \\
\hline
\end{tabular}

+ indicates that the miRNA promotes LVR, - indicates that the miRNA inhibits LVRCMR, cardiac magnetic resonance; d, day; Echo, echocardiography; EDV, end-diastolic volume; $\mathrm{m}$, month(s); LVEDV, left ventricle end-diastolic volume; LVEF, left ventricle ejection fraction; LVESV, left ventricle end systolic volume; PCI, percutaneous coronary intervention; MI, myocardial infarction; NT-pro-BNP, pro-brain natriuretic peptide; STEMI, ST-elevation myocardial infarction; UA, unstable angina; y, year. Arrow means an increase.

miR-1 was recently proposed as a prognostic biomarker for post-MI LVR [87]. Ma and colleagues investigated 80 patients with first-time MI with ST-elevation. One and six months after the MI event, the patients underwent cardiac magnetic resonance (CMR) with measurement of LVR parameters and the changes in left ventricle ejection fraction (\%LVEF), left ventricle end-diastolic volume (\%LVEDV), and left ventricle end systolic volume (\%LVESV). With LVR defined as a minimum of $10 \%$ increase in LVEDV, miR-1 at admission showed a positive correlation with $\% \triangle \mathrm{LVEDV}$ and $\% \triangle \mathrm{LVESV}$, but not with $\% \Delta \mathrm{LVEF}$ in 22 patients. In addition, miR-1 was correlated with clinical biomarkers (especially $\mathrm{N}$-terminal pro-brain natriuretic peptide-NT-proBNP, but also with creatine kinase MB- 
CK-MB and cardiac troponin- $\mathrm{CTn}$ also). Therefore, an increase in plasma miR-1 levels was associated with a negative outcome regarding LVR after MI.

This study contradicts the findings of Grabmeier et al. In 2017, the study group investigated the prognostic value of four miRNAs (miR-1, miR-21, miR-29b, and miR-92) in 44 patients with MI from the SITAGRAMI study [81]. Blood samples were collected on days 4, 9, and 6 months after MI, CMR assessment (infarct volume (IV), LVEF, and LVEDV) was obtained on day $4( \pm 2)$ and six months after MI, and absolute changes in these parameters were calculated. The serial measurements for these miRNAs revealed the same pattern for miR-1 and miR-21 (increase on day 4 and 9 with a decrease to day 4 values at the 6-month follow-up), an ascending pattern for miR-29b, and no change for miR-92 levels. Of the four miRNAs, miR-1 and miR-29b correlated with lower infarct volume and only miR-29b with lower LVEDV. Thus, an increase in miR-1 and miR-29b concentrations was associated with a favorable outcome concerning LVR after MI.

In 2011, Zile et al. described the first temporal profile of 5 miRNAs (miR-1, miR-21, miR-29a, miR-133a, and miR-208) in 12 patients with MI [89]. Blood samples were collected on days 2, 5, 28, and 90 post-MI. LVEDV was measured by echocardiography on days 1 , 5,28 , and 90 post-MI and showed a time-dependent increase. Compared with controls, the miR-1 level decreased on day 2 , increased on day 5 , and remained unchanged through day 90 post-MI. MiR-21 decreased on day 2, increased on day 5, and returned to normal on day 90 post-MI. MiR-29a levels were not modified on day 2, increased on day 5 but returned to normal levels by day 90 . MiR-133 and miR-208 were unchanged on day 2, increased on day 5 , and remained elevated through day 90 . Of note, only day $5 \mathrm{miR}-29 \mathrm{a}$ levels showed a positive association with day 90 LVEDV. These findings suggest that miR-1 has no prognostic value for post-MI LVR and that early miR-29a increase in the blood correlates with a negative outcome of post-MI LVR.

The promising role of miR-21 as a biomarker of LVR has also been investigated in human trials. The study group of Dubois explored the role of superoxide dismutase 2 (SOD2), a major antioxidant enzyme, and three circulating miRNAs (miR-21, miR-222, and miR-23) in patients with MI [91]. They used blood samples from the Remodelage Ventriculaire-2 (REVE-2) multicenter study patients, which enrolled 246 probands with a first anterior wall Q-wave MI. The patients underwent periodical (three months and one year) echocardiographic evaluation and blood sampling and were divided into a no $L V R$ or a high LVR group, according to the echocardiography results. The circulating levels of the three miRNAs and their target, SOD2, were associated with high LVR after myocardial infarction.

Gao and colleagues found a positive association between miR-21 serum levels and the neutrophil-lymphocyte ratio in 184 patients with MI [92]. The 30-day survival rate of patients with high miR-21 serum levels and the elevated neutrophil-lymphocyte ratio was significantly lower than patients with low miR-21 expression and low neutrophillymphocyte ratio, suggesting that miR-21 can be used as an independent predictor for survival post-MI.

Liu et al. analyzed $198 \mathrm{MI}$ patients to assess the possible use of miR-21 or miR-146a as LVR predictors [93]. All patients were evaluated by echocardiography (LVEF, LVEDV, LVESV) on day five and one year after percutaneous coronary intervention (PCI), and blood samples were collected on day five after PCI. LVR was defined as an increase of at least $20 \%$ in LVEDV one year after MI $(n=56)$. They also evaluated plasma levels of CK-MB, cTnI, C Reactive Protein, NT-proBNP, leukocytes and calculated the estimated Glomerular Filtration Rate. MiR-21 correlated with cTnI, and miR-146 was associated with CRP and leukocyte count. The results showed that both miR-21 or miR-146a could be used as early biomarkers of LVR, and their combination might have a higher predictive power. On day five, both miRNAs showed a higher concentration in the LVR group compared to controls. While for miR-21, which has a proven pro-fibrotic role, these findings are expected, for miR-146, which has an anti-fibrotic role, these results are rather surprising and might be explained by its proinflammatory function. 
Maciejak et al. used digital PCR to monitor miR-30a-5p levels in plasma and serum. They found significant elevations on admission in MI patients who had developed heart failure at the 6-month follow-up (defined by LVEF $\leq 50 \%$, NT-proBNP $\geq 150 \mathrm{pg} / \mathrm{mL}$ ). In this study, the role of miR-30 was described as pro-fibrotic. A GO (Gene Ontology) and KEGG (Kyoto Encyclopedia of Genes and Genomes) analysis identified fibroblast growth factor signaling via the PI3K/AKT pathway, which plays a crucial role in LVR as a key pathway miR-30a-5p [94]. However, these results should be interpreted cautiously, given the small sample size $(n=14)$ and the cut-off values for defining the HF and non-HF groups.

In 2014, Pin et al. assessed the prognostic significance of miR-34a and miR-208b levels in blood sampled in admission on a large cohort $(n=359)$ of MI patients [95]. Echocardiography was performed after admission (day 1-4) and at the 6-month follow-up. LVR parameters were measured, and an increase of more than $10 \%$ in LVEDV defined the cardiac remodeling group $(n=116)$. Both miRNAs showed higher blood levels in the LVR group compared with the non-LVR group. The primary endpoint consisting of cardiovascular death or heart failure (clinical symptoms, LVEF $<40 \%$ and high NT-proBNP levels) was noted in 83 patients and associated with significantly increased miR-208b and miR-34a levels. Furthermore, the combination of these two plasma miRNAs outperformed NT-proBNP in both LVR and endpoint prediction after MI.

Zhang et al. also proposed a prognostic role of miR-92a for LVR after MI [41]. The study cohort consisted of $60 \mathrm{MI}$ patients who underwent PCI. Echocardiography was performed before and at three months after PCI and included EF, LVEDV, LVESV, and LV wall thickness measurements. High blood levels of miR-92 on admission positively correlates with LVEDV, LVESV, and LV wall thickness and negatively with LVEF at three months. This confirms the pro-fibrotic role of miR-92 in the previous studies but contradicts the findings of Grabmeier et al., which found no detectable changes in miR-92 levels after MI [88].

While previous studies suggested that miR-133 and miR-423-5p can be used as heart failure biomarkers, Bauters et al. showed that these miRNAs were not associated with LVR echocardiographic parameters (LVEF, LVEDV, and LVESV), brain natriuretic peptide, cTnI, or $C$ reactive protein over one year [99]. The study population consisted of 246 patients with anterior Q-wave MI, so an inadequate sample size could not explain the result, especially since other miRNAs (e.g., miR-21) investigated in blood samples from the same study (REVE-2) showed various degrees of association. The result was confirmed by Zile et al. [96].

The first study to report the use of miR-150 as a prognostic biomarker for LVR emerged in 2013 [97,101]. The authors used an in-silico approach to select which miRNAs would most likely be involved in the development of LVR and retrieved 13 genes known to be associated with LVR and, later on, 265 miRNAs targeting these genes. Then, using an interaction network, they selected ten miRNAs, out of which, based on blood analysis findings, two miRNAs emerged as possible candidates: miR-150 and miR-101. Finally, they chose miR-150 due to its deregulation in cardiac hypertrophy. Subsequently, the study group demonstrated that miR-150 is overexpressed in the infarcted tissues of mice subjected to experimental (coronary ligation) MI.

Furthermore, they showed that miR-150 regulates LVR by inhibiting C-reactive protein and adrenergic receptor beta 1 expression. Of note, the authors used a derivation cohort (60 patients divided into two groups based on whether they presented with LVR, as assessed by echocardiography $-\Delta$ End Diastolic Volume), as well as a validation cohort (the subjects underwent cardiac magnetic resonance to determine whether LVR is present after MI). They reported a higher predictive power of miR-150 for LVR than NT-proBNP, or a multiparameter model including serum markers at admission, age, and sex. They concluded that LVR is associated with low circulating levels of miR-150 after the first MI [97].

Later that year, the same authors published data evaluating a signature combination of four miRNAs (miR-16/27a/101/150) to predict post-MI LVR [90]. One hundred fifty 
patients with MI were enrolled in the study, blood samples were obtained at discharge (to determine NT-proBNP plasma levels and the four miRNAs), but this time the wall motion index score as an indicator for LV systolic dysfunction was applied. They built two multi-variable models to assess LV contractility: one model included clinical variables, including NT-proBNP, and the second model included all the parameters of model 1 and the four miRNAs. Patients with anterior MI or a history of MI and elevated NT-proBNP were at high risk of impaired LV contractility. Patients with low levels of miR-150/101 or elevated levels of miR-16/27a were also at increased risk of poor LV contractility. Statistical analysis confirmed that the panel of four miRNAs improved the prognostic value of the multi-variable clinical model, including NT-proBNP.

The two papers published by Devaux and colleagues correlate with data supporting the role of miR-150 in cell proliferation, migration, and differentiation and designate miR150 as a promising prognostic biomarker for the clinical outcome post-MI; nevertheless, more complex studies are required to refine this hypothesis further.

The role of miR-208 as a MI prognostic value was investigated in four studies. As mentioned above, Lv et al. confirmed the prognostic power of miR-208b and miR-34a in a large sample of patients [95].

In 2017, Liu and colleagues proved that miR-208 could serve as a predictor for post-MI LVR [98]. The study cohort consisted of 100 MI patients (of which 59 underwent PCI), 80 patients with unstable angina, and 80 healthy controls. Venous blood samples were collected on admission and after PCI. Echocardiographic assessment of cardiac function (LVEDV, LVESV, and LVEF) was completed on admission and at the 6-month follow-up. The LVR group was defined as at least a $10 \%$ increase in LVEDV from baseline $(n=14)$. Major clinical cardiovascular events (MACE) were evaluated in all MI patients who underwent PCI $(n=20)$. Circulating miR-208b levels were significantly higher in MI patients than in unstable angina patients and healthy controls. Additionally, miR-208b level was increased in three-vessel coronary artery disease (CAD) patients compared to single- and two-vessel CAD. Last but not least, miR-208b blood levels were higher in the LVR and MACE groups. Interestingly, the plasma level of miR-208b was significantly decreased after PCI compared to levels before PCI.

In 2018, Alavi-Maghaddam et al. published the results of a pilot study in which they investigated whether miR-208b can be used as a predictor of 6-month survival time after MI [99]. The study enrolled 21 MI patients with ST-elevation, among which seven (the non-survivor group) died within six months after MI. The plasma levels of circulating miR-208b were significantly higher compared to the survivor group. This preliminary, small study results showed that miR-208b could serve as an indicator of survival six months after MI.

Collectively, these findings support the notion that miR-208b has a negative correlation with the improvement of cardiac function and may be a potential predictor of post-MI LVR.

In a study conducted by de Gonzalo-Calvo and colleagues, miR-1254 showed a significant association with cardiac magnetic resonance (CMR) variables (positive with LV ejection fraction and negative with LV end-diastolic volume index and LV end-systolic volume index) [100]. They identified miR-1254 as an independent predictor of LVR in patients after one week, respectively, and six months (with multivariate adjustment including clinical, CMR variables, hs-troponin-T, and NT-proBNP) after MI with ST-elevation.

The prognostic value of miR-1 has been investigated in three studies, all with a different outcome. Given its anti-fibrotic and antihypertrophic role, high levels of miR-1 should be associated with a lack of cardiac remodeling [102]. The same dilemma applies to miR-29 and miR-30a studies. For miR-29, two studies show opposing results, although both suggest miR-29 can be used as a predictor for MI. While overexpression of miR-30a in rats had a cardioprotective effect, in human trials, it was associated with LVR.

The contradictory conclusions of these studies might be explained mainly by the different methods used to assess (CMR vs. echo) and define LVR (absolute change vs. percentage, LVDEV vs. LVEF, echo parameters vs. paraclinical markers), although the time 
frames for clinical and paraclinical evaluation (three months vs. six months vs. one year) and the diverse inclusion or exclusion criteria (STEMI vs. all types of MI) should also be taken into consideration.

To solve some of these impediments, we advance some suggestions from a clinical perspective. First, we would like to emphasize the necessity for a standardized, easy-to-use definition for left ventricle remodeling. The use of echocardiography should become a standard since it is accessible in most hospitals, it is non-invasive, easily repeatable, safe, quick, and does not require ultra-specialized training. Combining three, easy to measure parameters, such as LVED, LVESV, and LVEF provides a clear image of the cardiac function post-MI. Lately, the global longitudinal strain has emerged as a less operator-dependent parameter for LVR, but further evidence is required [103]. In addition, a standardized timeline (on admission, at discharge, at the 1-month, 6-month, and 1-year follow-ups, and after that, annually) for these evaluations should be implemented.

As for miRNA evaluation, we propose an early (either on admission or at discharge) single-point measurement of miRNAs with putative prognostic power. This would overcome the typical challenges associated with miRNA studies, such as the time-dependent changes of the circulant plasma following MI. Furthermore, one should remember that almost $50 \%$ of patients are non-compliant because of forgetfulness, medication costs, inability to get a prescription/consultation, poor doctor-patient relationship, or adverse side-effect of medication $[104,105]$. Therefore, the sooner we can appreciate the development post-MI, the better we can control it.

For miR-21, miR-150, and miR-208, the studies arrive at the same conclusion, underlining the need for further, more complex analyses aiming to refine their prognostic and therapeutic value. Further confirmations on much larger cohorts are required for the rest of the miRNAs reviewed, including miR-34 and miR-146. Lastly, we want to underline that combining multiple miRNAs (for example, miR-16/27a/101/150, miR-21, and miR146 or miR-34 and miR-208) has higher predictive power for LVR compared to a single miRNA measurement.

\section{4. miRNA as Therapeutic Targets}

Although the last decade's research has vastly expanded our knowledge on the therapeutic applications of microRNAs in acute myocardial infarction, the clinical translation still faces many challenges; one of the most important is the targeted delivery of miRNAs. Delivering microRNAs into an infarcted heart is not a simple task since multiple issues have to be taken into consideration for a successful approach: the timing of administration, the route of administration (intracardiac injection in the infarcted area/periphery of infarcted area, intravenous administration), the packaging of the small ARN (exosomes, lentiviral, synthetic nanoparticles, nanocarriers).

$\mathrm{Li}$ et al. used lentiviral vectors to overexpress miR-7a/b to reduce fibrosis apoptosis and cardiac remodeling and improve cardiac function in a mouse model of myocardial infarction [13].

Direct intracardiac injection of agomiR-21 and agomiR-146a conjugated with cholesterol moieties has been shown to significantly reduce apoptosis in the infarcted hearts of Kunming mice [26].

Chen et al. injected intramyocardially miR-133-conditioned mesenchymal stem cells and reported a reduction of apoptosis and the infarct size and a significant increase in cardiac function in a rat model of acute myocardial infarction an effect presumably mediated by the local release of miR-133 [106].

The administration of antimiR-21 by intracoronary perfusion in pigs subjected to transient percutaneous occlusion of the left coronary artery suppressed pathological post-MI fibrosis and the inflammatory response in macrophages [107]. Interestingly, the use of anti-miR-21-coated stents leads to an efficient reduction of in-stent restenosis, with no significant off-target side effects [108,109]. Bellera and colleagues showed that a single, early (at the reperfusion time) intracoronary administration of encapsulated in polylac- 
tidecoglycolide anti-miR-92 stimulates angiogenesis and prevents LVR in an adult pig model of AMI, without evidence of systemic or local adverse effects [42].

One of the most frequently used delivery methods is represented by exosomes. Exosomes are 30-100 $\mathrm{nm}$ wide, CD9/63/81 positive extracellular vesicles can transfer proteins, mRNAs, and microRNAs between cells, thus being involved in intercellular communication [110]. Due to their low immunogenicity profile, exosomes are well tolerated, and, depending on their surface, antigens can target specific cells, properties that make them ideal therapeutic delivery tools.

Song et al. injected miRNA-21-enriched exosomes (isolated from conditioned HEK293T cells) directly into the infarcted area and documented a rapid (four hours) uptake of miR-21 in both cardiomyocytes and endotheliocytes, followed by a significant attenuation of apoptosis and improvement of cardiac function [111]. Ma et al. used mesenchymal cells-derived exosomes injected intramyocardially to deliver miR-132 in infarcted mouse hearts and described an improved vascularization in the peri-infarcted area, with significant enhancement of cardiac function [112]. Early intravenous administration of exosomes derived from miR-146a-conditioned adipose-derived stem cells significantly reduced the cardiac damage and improved cardiac function in a rat model of acute myocardial infarction [113]. Zhao et al. injected intramyocardially exosomes derived from mesenchymal stromal cells and showed that exosomal miR-182 reduced cardiac inflammation and infarct size in a mouse model of myocardial infarction [114]. Charles et al. reported a significant reduction in the infarcted size and improved cardiac function after IV administration of MSC-derived exosomes as early as day seven post-infarction [115].

However, the therapeutic use of exosomes is still hampered by its low and variable recovery yield from cell cultures, their widely heterogeneous size, and the cumbersome purification procedures $[116,117]$. Alternatives to the exosome, such as targeted modified nanoparticles and low molecular weight heparin (LMWH) nanocarriers, have been recently proposed. Hyaluronan-sulfate miR-21-carrying anionic targeted at macrophages in the infarcted area turned them in reparative mode and significantly reduced fibrosis and apoptosis, with enhanced cardiac function [118]. Even more exciting, LMWH nanocarriers loaded with anti-miR-1 overcame micro-thrombotic obstruction and reduced cardiomyocyte apoptosis, cardiac fibrosis, and promoted tissular repair [119].

\section{Conclusions}

As outlined in this article, miRNAs are essential regulators of post-MI cardiac remodeling. MiRNAs can control the post-MI cardiac fibrotic process in its entirety, thus providing new therapeutic targets for fibrosis therapy. The manipulation of multifunctional miRNAs into therapeutic drugs may hold the key to controlling a complex disease such as cardiac remodeling. Furthermore, they could serve as novel prognostic biomarkers of post-MI LVR, which can be used in the long-term follow-up of MI patients. With this review, we hope to shine some light on the miRNA-based diagnostic, prognostic, and therapeutics of cardiac remodeling after myocardial infarction.

\section{Clinical Perspective}

The management of MI patients needs novel, more sensitive, and specific diagnostic, prognostic, and predictive biomarkers; some of the microRNAs discussed in the present review fulfills these criteria. Furthermore, given their function in the infarcted tissue, they might also qualify as therapeutic tools.

For several miRNAs, the diagnostic role in MI has been well established, even with the same or higher sensitivity and specificity than traditional biomarkers.

A prognostic biomarker can help the physician predict the outcome and overall survival of a MI patient receiving standard or no treatment. A predictive biomarker aids the clinician in making tailored treatment decisions (drug or dosage selection). So far, miRNAs have been intensively investigated as predictive biomarkers, mostly in different types of cancer. Identifying miRNAs with predictive power post-MI would be a valuable way to 
distinguish which patients are likely or unlikely to benefit from a particular treatment. For example, a patient with high plasma levels of pro-fibrotic miRNAs, such as miR-21, miR-155, and miR-208, might benefit from an increased number of follow-up visits, regular cardiac function evaluation (both non-invasive and invasive, if necessary), higher dosage for drugs that prevent LVR (angiotensin-converting-enzyme inhibitors and angiotensin II receptor blockers), more extended periods of administration of a high dosage of statins or dual antiplatelet therapy in patients, cardiac rehabilitation and home monitoring.

The therapeutic role of miRNAs with post-MI LVR is the most fascinating. Therapy with anti- or ago-miRs has been evaluated in mice, rats, or pig models, but, so far, not in humans. Further studies are needed to establish standardized miRNA (cocktail) therapeutic protocols, addressing obstacles such as design optimization, method and timing of delivery, and, most important, defining targeted delivery to specific cardiac cells without local or systemic side effects.

However, we are halfway down the road by identifying diagnostic and prognostic miRNAs and testing some therapeutic ones in vivo.

Author Contributions: Conceptualization, L.M., and A.A.; Resources, F.G. and R.S.; WritingOriginal Draft Preparation, L.M., I.O.S.; Writing-Review and Editing, A.A., C.M. and I.O.S.; Visualization, R.S. and F.G.; Supervision, A.A., I.O.S. All authors have read and agreed to the published version of the manuscript.

Funding: This research received no external funding.

Conflicts of Interest: The authors declare no conflict of interest.

\section{References}

1. OECD/EU. Mortality following acute myocardial infarction (AMI). In Health at a Glance: Europe 2016: State of Health in the EU Cycle; OECD Publishing: Paris, France, 2016.

2. Ibanez, B.; James, S.; Agewall, S.; Antunes, M.J.; Bucciarelli-Ducci, C.; Bueno, H.; Caforio, A.L.P.; Crea, F.; Goudevenos, J.A.; Halvorsen, S.; et al. 2017 ESC Guidelines for the management of acute myocardial infarction in patients presenting with ST-segment elevation: Task Force for the management of acute myocardial infarction in patients presenting with ST-segment elevation of the European Society of Cardiology (ESC). Eur. Heart J. 2018, 39, 119-177.

3. Martin, G.; St John, S.; Sharpe, N. Left Ventricular Remodeling after MI. Circulation 2000, 101, 2981-2988.

4. Hinderer, S.; Schenke-Layland, K. Cardiac fibrosis-A short review of causes and therapeutic strategies. Adv. Drug Deliv. Rev. 2019, 146, 77-82. [CrossRef] [PubMed]

5. Aimo, A.; Gaggin, H.K.; Barison, A.; Emdin, M.; Januzzi, J.L. Imaging, Biomarker, and Clinical Predictors of Cardiac Remodeling in Heart Failure with Reduced Ejection Fraction. JACC Heart Fail. 2019, 7, 782-794. [CrossRef] [PubMed]

6. Gravning, J.; Smedsrud, M.K.; Omland, T.; Eek, C.; Skulstad, H.; Aaberge, L.; Bendz, B.; Kjekshus, J.; Mørkrid, L.; Edvardsen, T. Sensitive troponin assays and N-terminal pro-B-type natriuretic peptide in acute coronary syndrome: Prediction of significant coronary lesions and long-term prognosis. Am. Heart J. 2013, 165, 716-724. [CrossRef] [PubMed]

7. Bartel, D.P. MicroRNAs: Genomics, biogenesis, mechanism, and function. Cell 2004, 116, 281-297. [CrossRef]

8. Dobaczewski, M.; Chen, W.; Frangogiannis, N.G. Transforming growth factor (TGF)- $\beta$ signaling in cardiac remodeling. J. Mol. Cell. Cardiol. 2011, 51, 600-606. [CrossRef]

9. Ma, Z.-G.; Yuan, Y.-P.; Wu, H.-M.; Zhang, X.; Tang, Q.-Z. Cardiac fibrosis: New insights into the pathogenesis. Int. J. Biol. Sci. 2018, 14, 1645-1657. [CrossRef] [PubMed]

10. Travers, J.G.; Kamal, F.A.; Robbins, J.; Yutzey, K.E.; Blaxall, B.C. Cardiac Fibrosis: The Fibroblast Awakens. Circ. Res. 2016, 118, 1021-1040. [CrossRef] [PubMed]

11. Derynck, R.; Zhang, Y. Smad-dependent and Smad-independent pathways in TGF- $\beta$ family signalling. Nature 2003, 425, 577-584. [CrossRef]

12. Zhang, Y.E. Non-Smad pathways in TGF- $\beta$ signaling. Cell Res. 2009, 19, 128-139. [CrossRef] [PubMed]

13. Li, R.; Geng, H.H.; Xiao, J.; Qin, X.T.; Wang, F.; Xing, J.H.; Xie, Y.-F.; Mao, Y.; Liang, J.-W.; Ji, X.P. miR-7a/b attenuates postmyocardial infarction remodeling and protects H9c2 cardiomyoblast against hypoxia-induced apoptosis involving Sp1 and PARP-1. Sci. Rep. 2016, 6, 29082. [CrossRef] [PubMed]

14. Xiao, Y.; Zhang, Y.; Chen, Y.; Li, J.; Zhang, Z.; Sun, Y.; Shen, H.; Zhao, Z.; Huang, Z.; Zhang, W.; et al. Inhibition of MicroRNA-9-5p Protects Against Cardiac Remodeling Following Myocardial Infarction in Mice. Hum. Gene Ther. 2019, 30, 286-301. [CrossRef] [PubMed]

15. Hullinger, T.G.; Montgomery, R.L.; Seto, A.G.; Dickinson, B.A.; Semus, H.M.; Lynch, J.M.; Dalby, C.M.; Robinson, K.; Stack, C.; Latimer, P.A.; et al. Inhibition of miR-15 Protects Against Cardiac Ischemic Injury. Circ. Res. 2012, 110, 71-81. [CrossRef] [PubMed] 
16. Zeng, Y.L.; Zheng, H.; Chen, Q.R.; Yuan, X.H.; Ren, J.H.; Luo, X.F.; Chen, P.; Lin, Z.Y.; Chen, S.Z.; Wu, X.Q.; et al. Bone marrow-derived mesenchymal stem cells overexpressing MiR-21 efficiently repair myocardial dam-age in rats. Oncotarget 2017, 8, 29161-29173. [CrossRef]

17. Gao, F.; Kataoka, M.; Liu, N.; Liang, T.; Huang, Z.-P.; Gu, F.; Ding, J.; Liu, J.; Zhang, F.; Ma, Q.; et al. Therapeutic role of miR-19a/19b in cardiac regeneration and protection from myocardial infarction. Nat. Commun. 2019, 10, 1-15. [CrossRef]

18. Deng, W.; Wang, Y.; Long, X.; Zhao, R.; Wang, Z.; Liu, Z.; Cao, S.; Shi, B. miR-21 Reduces Hydrogen Peroxide-Induced Apoptosis in c-kit+ Cardiac Stem Cells In Vitro through PTEN/PI3K/Akt Signaling. Oxidative Med. Cell. Longev. 2016, 2016, 1-14. [CrossRef]

19. Sabatel, C.; Malvaux, L.; Bovy, N.; Deroanne, C.; Lambert, V.; Gonzalez, M.-L.A.; Colige, A.; Rakic, J.-M.; Noel, A.; Martial, J.A.; et al. MicroRNA-21 Exhibits Antiangiogenic Function by Targeting RhoB Expression in Endothelial Cells. PLoS ONE 2011, 6, e16979. [CrossRef]

20. Huang, Z.; Wu, S.; Kong, F.; Cai, X.; Ye, B.; Shan, P.; Huang, W. MicroRNA-21 protects against cardiac hypoxia/reoxygenation injury by inhibiting excessive autophagy in H9c2 cells via the Akt/mTOR pathway. J. Cell. Mol. Med. 2017, 21, 467-474. [CrossRef]

21. Yang, Q.; Yang, K.; Li, A.Y. Trimetazidine protects against hypoxia-reperfusion-induced cardiomyocyte apoptosis by in-creasing microRNA-21 expression. Int. J. Clin. Exp. Pathol. 2015, 8, 3735-3741.

22. Yang, F.; Liu, W.; Yan, X.; Zhou, H.; Zhang, H.; Liu, J.; Yu, M.; Zhu, X.; Ma, K. Effects of mir-21 on Cardiac Microvascular Endothelial Cells After Acute Myocardial Infarction in Rats: Role of Phosphatase and Tensin Homolog (PTEN)/Vascular Endothelial Growth Factor (VEGF) Signal Pathway. Med. Sci. Monit. 2016, 22, 3562-3575. [CrossRef]

23. Han, Q.; Zhang, H.-Y.; Zhong, B.-L.; Zhang, B.; Chen, H. Antiapoptotic Effect of Recombinant HMGB1 A-box Protein via Regulation of microRNA-21 in Myocardial Ischemia-Reperfusion Injury Model in Rats. DNA Cell Biol. 2016, 35, 192-202. [CrossRef]

24. Yuan, J.; Chen, H.; Ge, D.; Xu, Y.; Xu, H.; Yang, Y.; Gu, M.; Zhou, Y.; Zhu, J.; Ge, T.; et al. Mir-21 Promotes Cardiac Fibrosis After Myocardial Infarction Via Targeting Smad7. Cell. Physiol. Biochem. 2017, 42, 2207-2219. [CrossRef] [PubMed]

25. Roy, S.; Khanna, S.; Hussain, S.R.A.; Biswas, S.; Azad, A.; Rink, C.; Gnyawali, S.; Shilo, S.; Nuovo, G.J.; Sen, C.K. MicroRNA expression in response to murine myocardial infarction: miR-21 regulates fibroblast metalloprote-ase-2 via phosphatase and tensin homologue. Cardiovasc. Res. 2009, 82, 21-29. [CrossRef] [PubMed]

26. Huang, W.; Tian, S.-S.; Hang, P.-Z.; Sun, C.; Guo, J.; Du, Z.-M. Combination of microRNA-21 and microRNA-146a Attenuates Cardiac Dysfunction and Apoptosis during Acute Myocardial Infarction in Mice. Mol. Ther.-Nucleic Acids 2016, 5, e296. [CrossRef]

27. Thum, T.; Gross, C.; Fiedler, J.; Fischer, T.; Kissler, S.; Bussen, M.; Galuppo, P.; Just, S.; Rottbauer, W.; Frantz, S.; et al. MicroRNA-21 contributes to myocardial disease by stimulating MAP kinase signalling in fibroblasts. Nature 2008, 456, 980-984. [CrossRef]

28. Hong, Y.; Cao, H.; Wang, Q.; Ye, J.; Sui, L.; Feng, J.; Cai, X.; Song, H.; Zhang, X.; Chen, X. MiR-22 may Suppress Fibrogenesis by Targeting TGF $\beta R$ I in Cardiac Fibroblasts. Cell. Physiol. Biochem. 2016, 40, 1345-1353. [CrossRef]

29. Wang, J.; Huang, W.; Xu, R.; Nie, Y.; Cao, X.; Meng, J.; Xu, X.; Hu, S.; Zheng, Z. MicroRNA-24 regulates cardiac fibrosis after myocardial infarction. J. Cell. Mol. Med. 2012, 16, 2150-2160. [CrossRef] [PubMed]

30. Icli, B.; Wara, A.; Moslehi, J.; Sun, X.; Plovie, E.; Cahill, M.; Marchini, J.; Schissler, A.; Padera, R.F.; Shi, J.; et al. MicroRNA-26a Regulates Pathological and Physiological Angiogenesis by Targeting BMP/SMAD1 Signaling. Circ. Res. 2013, 113, $1231-1241$. [CrossRef]

31. Xiao, L.; He, H.; Ma, L.; Da, M.; Cheng, S.; Duan, Y.; Wang, Q.; Wu, H.; Song, X.; Duan, W.; et al. Effects of miR-29a and miR-101a Expression on Myocardial Interstitial Collagen Generation After Aerobic Exercise in Myocardial-infarcted Rats. Arch. Med Res. 2017, 48, 27-34. [CrossRef] [PubMed]

32. Qi, H.; Liu, Y.; Li, S.; Chen, Y.; Li, L.; Cao, Y.; Mingyao, M.; Shi, P.; Song, C.; Li, B.; et al. Activation of AMPK Attenuated Cardiac Fibrosis by Inhibiting CDK2 via p21/p27 and miR-29 Family Pathways in Rats. Mol. Ther.-Nucleic Acids 2017, 8, 277-290. [CrossRef]

33. Van Rooij, E.; Sutherland, L.B.; Thatcher, J.E.; DiMaio, J.M.; Naseem, R.H.; Marshall, W.S.; Hill, J.A.; Olson, E.N. Dysregulation of microRNAs after myocardial infarction reveals a role of miR-29 in cardiac fibrosis. Proc. Natl. Acad. Sci. USA 2008, 105, 13027-13032. [CrossRef] [PubMed]

34. Chen, L.; Ji, Q.; Zhu, H.; Ren, Y.; Fan, Z.; Tian, N. miR-30a attenuates cardiac fibrosis in rats with myocardial infarction by inhibiting CTGF. Exp. Ther. Med. 2018, 15, 4318-4324. [CrossRef]

35. Duisters, R.F.; Tijsen, A.J.; Schroen, B.; Leenders, J.J.; Lentink, V.; van der Made, I.; Herias, V.; van Leeuwen, R.E.; Schellings, M.W.; Barenbrug, P.; et al. miR-133 and miR-30 Regulate Connective Tissue Growth Factor Implications for a Role of MicroRNAs in Myocardial Matrix Remodeling. Circ. Res. 2009, 104, 170-178. [CrossRef]

36. Chen, L.W. Relationship between myocardial microRNA-30a expression and myocardial fibrosis in rats post myocar-dial infarction. Chin. J. Cardiovasc. Dis. 2016, 44, 443-449.

37. Kim, J.O.; Park, J.H.; Kim, T.; Hong, S.E.; Lee, J.Y.; Nho, K.J.; Cho, C.; Kim, Y.S.; Kang, W.S.; Ahn, Y.; et al. A novel system-level approach using RNA-sequencing data identifies miR-30-5p and miR-142a-5p as key regulators of apoptosis in myocardial infarction. Sci. Rep. 2018, 8, 14638. [CrossRef]

38. Zhang, W.; Chang, H.; Zhang, H.; Zhang, L. MiR-30e Attenuates Isoproterenol-induced Cardiac Fibrosis through Suppressing Snai1/TGF-b Signaling. J. Cardiovasc. Pharmacol. 2017, 70, 362-368. [CrossRef] [PubMed]

39. Gambacciani, C.; Kusmic, C.; Meghini, F.; Rizzo, M.; Mariani, L.; Pitto, L. miR-29a and miR-30c negatively regulate DNMT 3a in cardiac ischemic tissues: Implications for car-diac remodelling. microRNA Diagn. Ther. 2013, 1, 35-45. [CrossRef] 
40. Huang, Y.; Qi, Y.; Du, J.-Q.; Zhang, D.-F. MicroRNA-34a regulates cardiac fibrosis after myocardial infarction by targeting Smad4. Expert Opin. Ther. Targets 2014, 18, 1-11. [CrossRef]

41. Zhang, C.; Wu, W.; Wang, C.; Zhou, X.; Xu, X.; Geng, P.; Zhu, J. Expression and function of miR-92a in ventricular remodeling after PCI treatment of acute myocardial in-farction. Int. J. Clin. Exp. Pathol. 2017, 10, 1158-1165.

42. Bellera, N.; Barba, I.; Rodriguez-Sinovas, A.; Ferret, E.; Asín, M.A.; Gonzalez-Alujas, T.; Pérez-Rodon, J.; Esteves, M.; Fonseca, C.; Toran, N.; et al. Single Intracoronary Injection of Encapsulated Antagomir-92a Promotes Angiogenesis and Prevents Ad-verse Infarct Remodeling. J. Am. Heart Assoc. 2014, 3, e000946. [CrossRef]

43. Li, Q.; Xie, J.; Li, J.; Gu, R.; Ding, l.; Wang, L.; Xu, B. Overexpression of microRNA-99a attenuates heart remodelling and improves cardiac performance after myo-cardial infarction. J. Cell. Mol. Med. 2014, 8, 919-928. [CrossRef] [PubMed]

44. Zhao, X.; Wang, Z.; Liao, X.; Zeng, Q.; Li, Y.; Hu, F.; Liu, Y.; Meng, K.; Qian, C.; Zhang, Q.; et al. MicroRNA-101a Inhibits Cardiac Fibrosis Induced by Hypoxia via Trageting TGF $\beta$ RI on Cardiac Fibroblasts. Cell. Physiol. Biochem. 2015, 35, 213-226. [CrossRef] [PubMed]

45. Pan, Z.; Sun, X.; Shan, H.; Wang, N.; Wang, J.; Ren, J.; Feng, S.; Xie, L.; Lu, C.; Yuan, Y.; et al. MicroRNA-101 Inhibited Postinfarct Cardiac Fibrosis and Improved Left Ventricular Compliance via the FBJ Osteosarcoma Oncogene/Transforming Growth Factor- $\beta 1$ Pathway. Circulation 2012, 126, 840-850. [CrossRef] [PubMed]

46. Nagpal, V.; Rai, R.; Place, A.T.; Murphy, S.B.; Verma, S.K.; Ghosh, A.K.; Vaughan, D.E. MiR-125b Is Critical for Fibroblast-toMyofibroblast Transition and Cardiac Fibrosis. Circulation 2016, 133, 291-301. [CrossRef]

47. Bie, Z.D.; Sun, L.Y.; Geng, C.L.; Meng, Q.G.; Lin, X.J.; Wang, Y.F.; Wang, X.B.; Yang, J. MiR-125b Regulates SFRP5 Expression to Promote Growth and Activation of Cardiac Fibroblasts: MiR-125b regulates SFRP5 in cardiac fibroblasts. Cell Biol. Int. 2016, 40, 1224-1234. [CrossRef]

48. Li, N.; Zhou, H.; Tang, Q. miR-133: A Suppressor of Cardiac Remodeling? Front. Pharmacol. 2018, 9, 903. [CrossRef]

49. Xiao, Y.; Zhao, J.; Tuazon, J.P.; Borlongan, C.V.; Yu, G. MicroRNA-133a and Myocardial Infarction. Cell Transplant. 2019, 28, 831-838. [CrossRef]

50. He, Q.; Wang, F.; Honda, T.; James, J.; Li, J.; Redington, A. Loss of miR-144 signaling interrupts extracellular matrix remodeling after myocardial infarction leading to worsened cardiac function. Sci. Rep. 2018, 8, 16886. [CrossRef]

51. Li, J.; Cai, S.X.; He, Q.; Zhang, H.; Friedberg, D.; Wang, F.; Redington, A.N. Intravenous miR-144 reduces left ventricular remodeling after myocardial infarction. Basic Res. Cardiol. 2018, 113, 36. [CrossRef]

52. Ibrahim, A.G.-E.; Cheng, K.; Marbán, E. Exosomes as Critical Agents of Cardiac Regeneration Triggered by Cell Therapy. Stem Cell Rep. 2014, 2, 606-619. [CrossRef] [PubMed]

53. Tang, Y.; Wang, Y.; Park, K.M.; Hu, Q.; Teoh, J.P.; Broskova, Z.; Ranganathan, P.; Jayakumar, C.; Li, J.; Su, H.; et al. MicroRNA-150 protects the mouse heart from ischaemic injury by regulating cell death. Cardiovasc. Res. 2015, 106, 387-397. [CrossRef] [PubMed]

54. Liu, Z.; Ye, P.; Wang, S.; Wu, J.; Sun, Y.; Zhang, A.; Ren, L.; Cheng, C.; Huang, X.; Wang, K.; et al. MicroRNA-150 Protects the Heart from Injury by Inhibiting Monocyte Accumulation in a Mouse Model of Acute Myocardial Infarction. Circ. Cardiovasc. Genet. 2015, 8, 11-20. [CrossRef] [PubMed]

55. Zhang, Y.; He, W.; Huang, Y.; Lu, Y.; Zhu, L.; Lin, L.; Li, J.; Xie, Q. GW28-e0427 MiR-155 in macrophage regulates cardiac function and fibrosis after myocardial infarction possibly through SOCS1-dependent inflammatory response. J. Am. Coll. Cardiol. 2017, 70, C12. [CrossRef]

56. Duygu, B.; Poels, E.M.; Juni, R.; Bitsch, N.; Ottaviani, L.; Olieslagers, S.; de Windt, L.J.; Martins, P.A.D.C. miR-199b-5p is a regulator of left ventricular remodeling following myocardial infarction. Non-coding RNA Res. 2017, 2, 18-26. [CrossRef]

57. Shyu, K.-G.; Wang, B.-W.; Cheng, W.-P.; Lo, H.-M. MicroRNA-208a Increases Myocardial Endoglin Expression and Myocardial Fibrosis in Acute Myocardial Infarction. Can. J. Cardiol. 2015, 31, 679-690. [CrossRef]

58. Hu, S.; Huang, M.; Li, Z.; Jia, F.; Ghosh, Z.; Lijkwan, M.A.; Fasanaro, P.; Sun, N.; Wang, X.; Martelli, F.; et al. MicroRNA-210 as a Novel Therapy for Treatment of Ischemic Heart Disease. Circulation 2010, 122, S124-S131. [CrossRef] [PubMed]

59. Yang, X.; Qin, Y.; Shao, S.; Yu, Y.; Zhang, C.; Dong, H.; Lv, G.; Dong, S. MicroRNA-214 Inhibits Left Ventricular Remodeling in an Acute Myocardial Infarction Rat Model by Suppressing Cellular Apoptosis via the Phosphatase and Tensin Homolog (PTEN). Int. Heart J. 2016, 57, 247-250. [CrossRef] [PubMed]

60. Liu, X.; Xu, Y.; Deng, Y.; Li, H. MicroRNA-223 Regulates Cardiac Fibrosis After Myocardial Infarction by Targeting RA-SA1. Cell Physiol. Biochem. 2018, 46, 1439-1454.

61. Yuan, H.; Gao, J. The role of miR-370 in fibrosis after myocardial infarction. Mol. Med. Rep. 2017, 15, 3041-3047. [CrossRef]

62. Seo, H.-H.; Lee, S.; Lee, C.Y.; Lee, J.; Shin, S.; Song, B.-W.; Kim, I.-K.; Choi, J.-W.; Lim, S.; Kim, S.W.; et al. Multipoint targeting of TGF- $\beta$ /Wnt transactivation circuit with microRNA 384-5p for cardiac fibrosis. Cell Death Differ. 2018, 26, 1107-1123. [CrossRef]

63. Tao, L.; Bei, Y.; Chen, P.; Lei, Z.; Fu, S.; Zhang, H.; Xu, J.; Che, L.; Chen, X.; Sluijter, J.P.; et al. Crucial Role of miR-433 in Regulating Cardiac Fibrosis. Theranostics 2016, 6, 2068-2083. [CrossRef] [PubMed]

64. Tolonen, A.M.; Magga, J.; Szabó, Z.; Viitala, P.; Gao, E.; Moilanen, A.M.; Ohukainen, P.; Vainio, L.; Koch, W.J.; Kerkelä, R.; et al. Inhibition of Let-7 microRNA attenuates myocardialremodeling and improves cardiac function postinfarctionin mice. Pharm. Res. Per. 2014, 2, e00056.

65. Chen, C.-Y.; Choong, O.K.; Liu, L.-W.; Cheng, Y.-C.; Li, S.-C.; Yen, C.Y.; Wu, M.-R.; Chiang, M.-H.; Tsang, T.-J.; Wu, Y.-W.; et al MicroRNA let-7-TGFBR3 signalling regulates cardiomyocyte apoptosis after infarction. EBioMedicine 2019, 46, 236-247. [CrossRef] [PubMed] 
66. Wang, J.; Liew, O.W.; Richards, A.M.; Chen, Y.-T. Overview of MicroRNAs in Cardiac Hypertrophy, Fibrosis, and Apoptosis. Int. J. Mol. Sci. 2016, 17, 749. [CrossRef] [PubMed]

67. Doebele, C.; Bonauer, A.; Fischer, A.; Scholz, A.; Reiss, Y.; Urbich, C.; Hofmann, W.-K.; Zeiher, A.M.; Dimmeler, S. Members of the microRNA-17-92 cluster exhibit a cell-intrinsic antiangiogenic function in endothelial cells. Blood 2010, 115, 4944-4950. [CrossRef] [PubMed]

68. Liu, K.; Hao, Q.; Wei, J.; Li, G.-H.; Wu, Y.; Zhao, Y.-F. MicroRNA-19a/b-3p protect the heart from hypertension-induced pathological cardiac hypertrophy through PDE5A. J. Hypertens. 2018, 36, 1847-1857. [CrossRef] [PubMed]

69. Zhou, J.; Wang, K.C.; Wu, W.; Subramaniam, S.; Shyy, J.Y.; Chiu, J.J.; Li, J.Y.; Chien, S. MicroRNA-21 targets peroxisome proliferators-activated receptor-alpha in an autoregulatory loop to modu-late flow-induced endothelial inflammation. Proc. Natl. Acad. Sci. USA 2011, 108, 10355-10360. [CrossRef]

70. Ge, Z.W.; Zhu, X.L.; Wang, B.C.; Hu, J.L.; Sun, J.J.; Wang, S.; Chen, X.J.; Meng, S.P.; Liu, L.; Cheng, Z.Y. MicroRNA-26b relieves inflammatory response and myocardial remodeling of mice with myocardial infarction by suppression of MAPK pathway through binding to PTGS2. Int. J. Cardiol. 2019, 280, 152-159. [CrossRef]

71. Chiang, M.H.; Liang, C.J.; Lin, L.C.; Yang, Y.F.; Huang, C.C.; Chen, Y.H.; Kao, H.L.; Chen, Y.C.; Ke, S.R.; Lee, C.W.; et al. miR-26a attenuates cardiac apoptosis and fibrosis by targeting ataxia-telangiectasia mutated in myocardial infarction. J. Cell. Physiol. 2020, 235, 6085-6102. [CrossRef]

72. Jie, Q.; Luo, X.; Ma, Z.; Zhang, B.; Li, S.; Zhang, J. Downregulation of miR-26b-5p, miR-204-5p, and miR-497-3p Expression Facilitates Exercise-Induced Physiological Cardiac Hypertrophy by Augmenting Autophagy in Rats. Front. Genet. $2020,11,78$.

73. Liu, Y.; Wang, Z.; Xiao, W. MicroRNA-26a protects against cardiac hypertrophy via inhibiting GATA4 in rat model and cultured cardiomyocytes. Mol. Med. Rep. 2016, 14, 2860-2866. [CrossRef]

74. Zhang, B.; Zhou, M.; Li, C.; Zhou, J.; Li, H.; Zhu, D.; Wang, Z.; Chen, A.; Zhao, Q. MicroRNA-92a Inhibition Attenuates Hypoxia/Reoxygenation-Induced Myocardiocyte Apoptosis by Targeting Smad7. PLoS ONE 2014, 9, e100298. [CrossRef]

75. Danielson, L.S.; Park, D.S.; Rotllan, N.; Chamorro-Jorganes, A.; Guijarro, M.V.; Fernandez-Hernando, C.; Fishman, G.I.; Phoon, C.K.; Hernando, E. Cardiovascular dysregulation of miR-17-92 causes a lethal hypertrophic cardiomyopathy and ar-rhythmogenesis. FASEB J. 2013, 27, 1460-1467. [CrossRef]

76. Carè, A.; Catalucci, D.; Felicetti, F.; Bonci, D.; Addario, A.; Gallo, P.; Bang, M.-L.; Segnalini, P.; Gu, Y.; Dalton, N.D.; et al. MicroRNA-133 controls cardiac hypertrophy. Nat. Med. 2007, 13, 613-618. [CrossRef] [PubMed]

77. He, B.; Xiao, J.; Ren, A.-J.; Zhang, Y.-F.; Zhang, H.; Chen, M.; Xie, B.; Gao, X.-G.; Wang, Y.-W. Role of miR-1 and miR-133a in myocardial ischemic postconditioning. J. Biomed. Sci. 2011, 18, 22. [CrossRef] [PubMed]

78. Pankratz, F. MicroRNA-155 Exerts Cell-Specific Antiangiogenic but Proarteriogenic Effects during Adaptive Neovascularizationm. Circulation 2015, 131, 1575-1589. [CrossRef] [PubMed]

79. He, W.; Huang, H.; Xie, Q.; Wang, Z.; Fan, Y.; Kong, B.; Huang, D.; Xiao, Y. MiR-155 Knockout in Fibroblasts Improves Cardiac Remodeling by Targeting Tumor Protein p53-Inducible Nuclear Protein 1. J. Cardiovasc. Pharmacol. Ther. 2016, $21,423-435$. [CrossRef] [PubMed]

80. Fasanaro, P.; D’Alessandra, Y.; Di Stefano, V.; Melchionna, R.; Romani, S.; Pompilio, G.; Capogrossi, M.C.; Martelli, F. MicroRNA210 Modulates Endothelial Cell Response to Hypoxia and Inhibits the Receptor Tyrosine Kinase Ligand Ephrin-A3. J. Biol. Chem. 2008, 283, 15878-15883. [CrossRef] [PubMed]

81. Mutharasan, R.K.; Nagpal, V.; Ichikawa, Y.; Ardehali, H. microRNA-210 is upregulated in hypoxic cardiomyocytes through Aktand p53-dependent pathways and exerts cytoprotective effects. Am. J. Physiol. Circ. Physiol. 2011, 301, H1519-H1530. [CrossRef]

82. Tijsen, A.J.; van der Made, I.; van den Hoogenhof, M.M.; Wijnen, W.J.; van Deel, E.D.; de Groot, N.E.; Alekseev, S.; Fluiter, K.; Schroen, B.; Goumans, M.J. The microRNA-15 family inhibits the TGFb-pathway in the heart. Cardiovasc. Res. 2014, $104,61-71$. [CrossRef]

83. Wei, C.; Kim, I.K.; Kumar, S.; Jayasinghe, S.; Hong, N.; Castoldi, G.; Catalucci, D.; Jones, W.K.; Gupta, S. NF-кB mediated miR-26a regulation in cardiac fibrosis. J. Cell. Physiol. 2013, 228, 1433-1442. [CrossRef]

84. Bernardo, B.C.; Gao, X.-M.; Winbanks, C.E.; Boey, E.J.H.; Tham, Y.K.; Kiriazis, H.; Gregorevic, P.; Obad, S.; Kauppinen, S.; $\mathrm{Du}, \mathrm{X}$.-J.; et al. Therapeutic inhibition of the miR-34 family attenuates pathological cardiac remodeling and improves heart function. Proc. Natl. Acad. Sci. USA 2012, 109, 17615-17620. [CrossRef]

85. Martins, P.A.D.C.; Salic, K.; Gladka, M.M.; Armand, A.-S.; Leptidis, S.; El Azzouzit, H.; Hansen, A.; Roo, C.J.C.-D.; Bierhuizen, M.F.A.; Van Der Nagel, R.; et al. MicroRNA-199b targets the nuclear kinase Dyrk1a in an auto-amplification loop promoting calcineurin/NFAT signalling. Nature 2010, 12, 1220-1227. [CrossRef]

86. Wang, X.; Wang, H.-X.; Li, Y.-L.; Zhang, C.-C.; Zhou, C.-Y.; Wang, L.; Xia, Y.-L.; Du, J.; Li, H.-H. MicroRNA Let-7i Negatively Regulates Cardiac Inflammation and Fibrosis. Hypertension 2015, 66, 776-785. [CrossRef] [PubMed]

87. Ma, Q.; Ma, Y.; Wang, X.; Li, S.; Yu, T.; Duan, W.; Wu, J.; Wen, Z.; Jiao, Y.; Sun, Z.; et al. Circulating miR-1 as a potential predictor of left ventricular remodeling following acute ST-segment myocar-dial infarction using cardiac magnetic resonance. Quant Imaging Med. Surg. 2020, 10, 1490-1503. [CrossRef]

88. Grabmaier, U.; Clauss, S.; Gross, L.; Klier, I.; Franz, W.; Steinbeck, G.; Wakili, R.; Theiss, H.; Brenner, C. Diagnostic and prognostic value of miR-1 and miR-29b on adverse ventricular remodeling after acute myocardial infarction-The SITAGRAMI-miR analysis. Int. J. Cardiol. 2017, 244, 30-36. [CrossRef] [PubMed] 
89. Zile, M.R.; Mehurg, S.M.; Arroyo, J.E.; Stroud, R.E.; DeSantis, S.M.; Spinale, F.G. Relationship Between the Temporal Profile of Plasma microRNA and Left Ventricular Remodeling in Pa-tients Following Myocardial Infarction. Circ. Cardiovasc. Genet. 2011, 4, 614-619. [CrossRef]

90. Devaux, Y.; Vausort, M.; McCann, G.; Kelly, D.; Collignon, O.; Ng, L.; Wagner, D.R.; Squire, I.B. A Panel of 4 microRNAs Facilitates the Prediction of Left Ventricular Contractility after Acute Myocardial Infarction. PLoS ONE 2013, 8, e70644. [CrossRef]

91. Dubois-Deruy, E.; Cuvelliez, M.; Fiedler, J.; Charrier, H.; Mulder, P.; Hebbar, E.; Pfanne, A.; Beseme, O.; Chwastyniak, M.; Amouyel, P.; et al. MicroRNAs regulating superoxide dismutase 2 are new circulating biomarkers of heart failure. Sci. Rep. 2017, 7, 1-10. [CrossRef]

92. Gao, C.; Zhao, D.; Wang, J.; Liu, P.; Xu, B. Clinical significance and correlation of microRNA-21 expression and the neutrophillymphocyte ratio in patients with acute myocardial infarction. Clinics 2019, 74, e1237. [CrossRef]

93. Liu, X.; Dong, Y.; Chen, S.; Zhang, G.; Zhang, M.; Gong, Y.; Li, X. Circulating MicroRNA-146a and MicroRNA-21 Predict Left Ventricular Remodeling after ST-Elevation Myocardial Infarction. Cardiology 2015, 132, 233-241. [CrossRef]

94. Maciejak, A.; Kostarska-Srokosz, E.; Gierlak, W.; Dluzniewski, M.; Kuch, M.; Marchel, M.; Opolski, G.; Kiliszek, M.; Matlak, K.; Dobrzycki, S.; et al. Circulating miR-30a-5p as a prognostic biomarker of left ventricular dysfunction after acute myocardial infarction. Sci. Rep. 2018, 8, 1-11. [CrossRef] [PubMed]

95. Lv, P.; Zhou, M.; He, J.; Meng, W.; Ma, X.; Dong, S.; Meng, X.; Zhao, X.; Wang, X.; He, F. Circulating miR-208b and miR-34a are associated with left ventricular remodeling after acute myocardial infarction. Int. J. Mol. Sci. 2014, 15, 5774-5788. [CrossRef]

96. Bauters, C.; Kumarswamy, R.; Holzmann, A.; Bretthauer, J.; Anker, S.D.; Pinet, F.; Thum, T. Circulating miR-133a and miR-423-5p fail as biomarkers for left ventricular remodeling after myocardial infarction. Int. J. Cardiol. 2013, 168, 1837-1840. [CrossRef]

97. Devaux, Y.; Vausort, M.; McCann, G.P.; Zangrando, J.; Kelly, D.; Razvi, N.; Zhang, L.; Ng, L.L.; Wagner, D.R.; Squire, I.B. MicroRNA-150 A Novel Marker of Left Ventricular Remodeling After Acute Myocardial Infarction. Circ. Cardiovasc. Genet. 2013, 6, 290-298. [CrossRef]

98. Liu, X.; Yuan, L.; Chen, F.; Zhang, L.; Chen, X.; Yang, C.; Han, Z. Circulating miR-208b: A Potentially Sensitive and Reliable Biomarker for the Diagnosis and Prognosis of Acute Myocardial Infarction. Clin. Lab. 2017, 63, 101-109. [CrossRef] [PubMed]

99. Alavi-Moghaddam, M.; Chehrazi, M.; Alipoor, S.D.; Mohammadi, M.; Baratloo, A.; Mahjoub, M.P.; Movasaghi, M.; Garssen, J.; Adcock, I.M.; Mortaz, E. A Preliminary Study of microRNA-208b after Acute Myocardial Infarction: Impact on 6-Month Survival. Dis. Markers 2018, 2018, 1-7. [CrossRef] [PubMed]

100. De Gonzalo-Calvo, D.; Cediel, G.; Bär, C.; Núñez, J.; Revuelta-Lopez, E.; Gavara, J.; Ríos-Navarro, C.; Llorente-Cortes, V.; Bodí, V.; Thum, T.; et al. Circulating miR-1254 predicts ventricular remodeling in patients with ST-Segment-Elevation Myocardial Infarction: A cardiovascular magnetic resonance study. Sci. Rep. 2018, 8, 15115. [CrossRef]

101. Vasilescu, C.; Rossi, S.; Shimizu, M.; Tudor, S.; Veronese, A.; Ferracin, M.; Nicoloso, M.; Barbarotto, E.; Popa, M.; Stanciulea, O.; et al. MicroRNA Fingerprints Identify miR-150 as a Plasma Prognostic Marker in Patients with Sepsis. PLoS ONE 2009, 4, e7405. [CrossRef] [PubMed]

102. Valkov, N.; King, M.E.; Moeller, J.; Liu, H.; Li, X.; Zhang, P. MicroRNA-1-Mediated Inhibition of Cardiac Fibroblast Proliferation Through Targeting Cyclin D2 and CDK6. Front. Cardiovasc. Med. 2019, 6, 65. [CrossRef]

103. Chung, H. Myocardial Longitudinal Strain in Prediction of Heart Failure after Acute Myocardial Infarction. Korean Circ. J. 2019, 49, 973-974. [CrossRef] [PubMed]

104. Kleinsinger, F. Working with the non-compliant patient. Perm. J. 2010, 14, 54-60. [CrossRef] [PubMed]

105. Kleinsingerm, F. Understanding Noncompliant Behavior: Definitions and Causes. Perm. J. 2003, 7, 18-21.

106. Chen, Y.; Zhao, Y.; Chen, W.; Xie, L.; Zhao, Z.A.; Yang, J.; Chen, Y.; Lei, W.; Shen, Z. MicroRNA-133 overexpression promotes the therapeutic efficacy of mesenchymal stem cells on acute myo-cardial infarction. Stem. Cell Res. Ther. 2017, 8, 268. [CrossRef] [PubMed]

107. Hinkel, R.; Ramanujam, D.P.; Kaczmarek, V.; Howe, A.; Klett, K.; Beck, C.; Dueck, A.; Thum, T.; Laugwitz, K.-L.; Maegdefessel, L.; et al. AntimiR-21 Prevents Myocardial Dysfunction in a Pig Model of Ischemia/Reperfusion Injury. J. Am. Coll. Cardiol. 2020, 75, 1788-1800. [CrossRef]

108. McDonald, R.A.; Halliday, C.A.; Miller, A.M.; Diver, L.A.; Dakin, R.S.; Montgomery, J.; McBride, M.W.; Kennedy, S.; McClure, J.D.; Robertson, K.E.; et al. Reducing In-Stent Restenosis: Therapeutic Manipulation of miRNA in Vascular Remodeling and Inflammation. J. Am. Coll. Cardiol. 2015, 65, 2314-2327. [CrossRef]

109. Wang, D.; Deuse, T.; Stubbendorff, M.; Chernogubova, E.; Erben, R.G.; Eken, S.M.; Jin, H.; Li, Y.; Busch, A.; Heeger, C.H.; et al. Local microRNA modulation using a novel anti-miR-21-eluting stent effectively prevents experimental in-stent restenosis. Arter. Thromb. Vasc. Biol. 2015, 35, 1945-1953. [CrossRef] [PubMed]

110. Valadi, H.; Ekström, K.; Bossios, A.; Sjöstrand, M.; Lee, J.J.; Lötvall, J. Exosome-mediated transfer of mRNAs and microRNAs is a novel mechanism of genetic exchange between cells. Nature 2007, 9, 654-659. [CrossRef]

111. Song, Y.; Zhang, C.; Zhang, J.; Jiao, Z.; Dong, N.; Wang, G.; Wang, Z.; Wang, L. Localized injection of miRNA-21-enriched extracellular vesicles effectively restores cardiac function after myocardial infarction. Theranostics 2019, 9, 2346-2360. [CrossRef]

112. Ma, T.; Chen, Y.; Chen, Y.; Meng, Q.; Sun, J.; Shao, L.; Yu, Y.; Huang, H.; Hu, Y.; Yang, Z.; et al. MicroRNA-132, Delivered by Mesenchymal Stem Cell-Derived Exosomes, Promote Angiogenesis in Myocardial Infarction. Stem Cells Int. 2018, $2018,1-11$. [CrossRef] 
113. Pan, J. Exosome derived from miR-146a modified adipose-derived stem cells attenuate acute myocardial infarction induced myocardial damage via downregulation of early growth response factor 1. J. Cell. Biochem. 2019, 129, 4433-4443. [CrossRef]

114. Zhao, J.; Li, X.; Hu, J.; Chen, F.; Qiao, S.; Sun, X.; Gao, L.; Xie, J.; Xu, B. Mesenchymal stromal cell-derived exosomes attenuate myocardial ischaemia-reperfusion injury through miR-182-regulated macrophage polarization. Cardiovasc. Res. 2019, 115, 1205-1216. [CrossRef] [PubMed]

115. Charles, C.J.; Li, R.R.; Yeung, T.; Mazlan, S.M.I.; Lai, R.C.; De Kleijn, D.P.V.; Lim, S.K.; Richards, A.M. Systemic Mesenchymal Stem Cell-Derived Exosomes Reduce Myocardial Infarct Size: Characterization with MRI in a Porcine Model. Front. Cardiovasc. Med. 2020, 7, 258. [CrossRef] [PubMed]

116. Lai, R.C.; Yeo, R.W.; Lim, S.K. Mesenchymal stem cell exosomes. Semin. Cell. Dev. Biol. 2015, 40, 82-88. [CrossRef] [PubMed]

117. Lazar, E.; Benedek, T.; Korodi, S.; Rat, N.; Lo, J.; Benedek, I. Stem cell-derived exosomes-An emerging tool for myocardial regeneration. World J. Stem Cells 2018, 10, 106-115. [CrossRef]

118. Bejerano, T.; Etzion, S.; Elyagon, S.; Etzion, Y.; Cohen, S. Nanoparticle Delivery of miRNA-21 Mimic to Cardiac Macrophages Improves Myocardial Remodeling after Myocardial Infarction. Nano Lett. 2018, 18, 5885-5891. [CrossRef] [PubMed]

119. Hong, T.; Wei, Y.; Xue, X.; Li, Y.; Dong, H.; Guo, X.; Shi, X.; He, B. A Novel Anti-Coagulative Nanocomplex in Delivering miRNA-1 Inhibitor Against Microvascular Obstruc-tion of Myocardial Infarction. Adv. Healthc. Mater. 2020, 9, 1901783. [CrossRef] 